\title{
Polymeric Materials as Potential Inhibitors Against SARS-CoV-2
}

\author{
Yunusa Umar ${ }^{1}$ (D) Sirhan Al-Batty ${ }^{1} \cdot$ Habibur Rahman $^{2}$ (D) Omar Ashwaq $^{1}$ (D) Abdulla Sarief $^{1} \cdot$ Zakariya Sadique $^{1}$. \\ P. A. Sreekumar ${ }^{1}$ (D) S. K. Manirul Haque ${ }^{1}$ (1)
}

Accepted: 22 August 2021 / Published online: 9 September 2021

(c) The Author(s), under exclusive licence to Springer Science+Business Media, LLC, part of Springer Nature 2021

\begin{abstract}
Recently discovered SARS-CoV-2 caused a pandemic that triggered researchers worldwide to focus their research on all aspects of this new peril to humanity. However, in the absence of specific therapeutic intervention, some preventive strategies and supportive treatment minimize the viral transmission as studied by some factors such as basic reproduction number, case fatality rate, and incubation period in the epidemiology of viral diseases. This review briefly discusses coronaviruses' life cycle of SARS-CoV-2 in a human host cell and preventive strategies at some selected source of infection. The antiviral activities of synthetic and natural polymers such as chitosan, hydrophobically modified chitosan, galactosylated chitosan, aminebased dendrimers, cyclodextrin, carrageenans, polyethyleneimine, nanoparticles are highlighted in this article. Mechanism of virus inhibition, detection and diagnosis are also presented. It also suggests that polymeric materials and nanoparticles can be effective as potential inhibitors and immunization against coronaviruses which would further develop new technologies in the field of polymer and nanoscience.
\end{abstract}

Keywords SARS-CoV-2 · Polymeric materials $\cdot$ Metal-based nanoparticles $\cdot$ Virus lifecycle $\cdot$ Detection $\cdot$ Diagnosis COVID-19

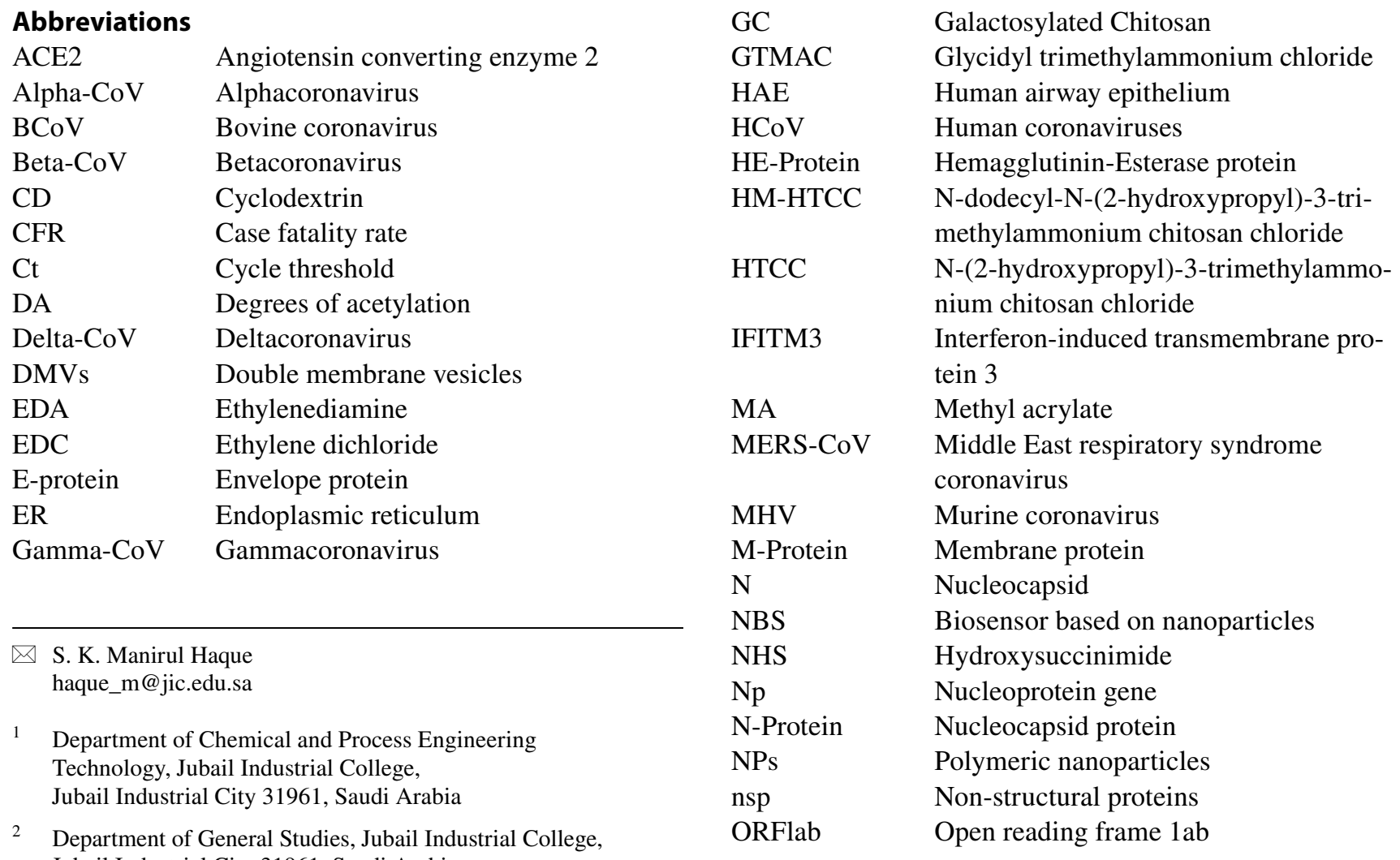




$\begin{array}{ll}\text { PAMAM } & \text { Poly amidoaminedendrimer } \\ \text { pcMNPs } & \begin{array}{l}\text { Poly (amino) carboxyl-coated magnetic } \\ \text { nanoparticles }\end{array} \\ \text { PCR } & \text { Polymerase chain reaction } \\ \text { PEI } & \text { Polyethyleneimine } \\ \text { PLGA } & \text { Poly (dl-lactide-co-glycolide) } \\ \mathrm{R}_{0} & \text { Reproduction number } \\ \mathrm{R}^{2} & \text { Correlation coefficient } \\ \text { RBD's } & \text { Receptor binding domains } \\ \text { RdRp } & \text { RNA-dependent RNA polymeras } \\ \text { RTCs } & \text { Replication -transcription complexes } \\ \text { RT-LAMP } & \text { Reversetranscription loop-mediated } \\ & \text { isothermal amplification } \\ \text { RT-PCR } & \text { Reverse transcription polymerase chain } \\ & \text { reaction } \\ \text { SARS-CoV-2 } & \text { Severe acute respiratory } \\ & \text { syndrome-coronavirus-2 } \\ \text { S-Protein } & \text { Spike protein } \\ \text { TMPRSS2 } & \text { Transmembrane protease, serine 2 } \\ \text { TMPTESS11D } & \text { Airway trypsin protease } \\ \text { VLPs } & \text { Virus like particles } \\ \text { WHO } & \text { World Health Organization }\end{array}$

\section{Introduction}

Following a series of human coronaviruses that have plagued the pages of human history [1], the newly discovered severe acute respiratory syndrome-coronavirus-2 (SARS-CoV-2) (Fig. 1) has emerged to become the highest risk to the global health care system, causing a worldwide outbreak of over hundred eighty million cases as of July 2, 2021. Coronaviruses resemble each other in their morphology and chemical structure; they are primarily zoonotic and found in avians and mammals. These viruses have been transmitted to the human system after being incubated through various

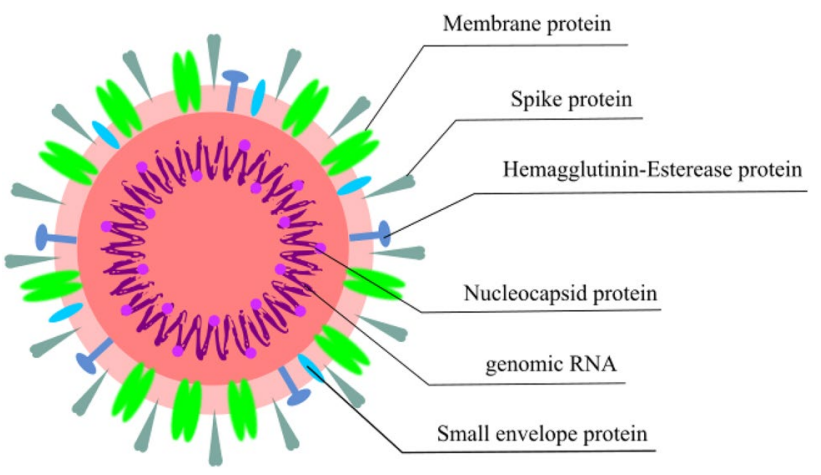

Fig. 1 Pictorial representation of SARS-CoV-2 with its five proteins, membrane protein (M-Protein), spike protein (S-Protein), hemagglutinin-esterase protein (HE-Protein), nucleocapsid protein (N-Protein), small envelope protein (E-protein) and its genomic RNA animal's hosts, causing severe acute illnesses and serious public health concerns across the globe.

Coronaviruses belong to the Coronaviridae family of the order nidovirales. The family Coronaviridae divided into two subfamilies named as Coronavirinae and Torovirinae. Coronavirinae is further subdivided into four genera called Alphacoronavirus (Alpha-CoV), Betacoronavirus (Beta-CoV), Gammacoronavirus (Gamma-CoV), and Deltacoronavirus (Delta-CoV). In contrast, Torovirinae has been further divided into Bafinivirus and Torovirus based on phylogenic relationships (Fig. 2). Alpha-CoV comprises human coronaviruses $(\mathrm{HCoV})$ such as $\mathrm{HCoV}-229 \mathrm{E}$ and $\mathrm{HCoV}-\mathrm{NL63}$, while Beta-CoV targets a wide range of mammalians, including mice and humans with $\mathrm{HCoV}$ HKU1, HCoV-OC43, SARS-CoV, Middle East respiratory syndrome coronavirus (MERS-CoV), murine coronavirus (MHV) and bovine coronavirus (BCoV). The Gamma-CoV and Delta-CoV infect mainly birds except for a beluga whale coronavirus that infects mammals. The Delta-CoV genus was discovered in 2012 and regrouped in different Coronavirus (HKU11, HKU12, HKU13) belonging to mammals to birds. Presently, seven strains of known human coronaviruses include 229E, NL63, OC43, HKU1, SARS-CoV, MERS-CoV, and SARS-CoV-2 [2]. The last three proved to be highly pathogenic that encountered wider host adaptability and competence to cause severe diseases in humans, mice, chickens, cats, camels, dogs, pigs, civet cats, and bats (Fig. 3). An Alpha-CoV, HCoV-229E and then a Beta-CoV, HCoV-OC43 was discovered in 1966 and1967, respectively. After a large gap, two more Beta-CoV, SARS-CoV and MERS-CoV, were first found in Hong Kong, China, and Jeddah, Saudi Arabia, in the years 2003 and 2012, respectively.

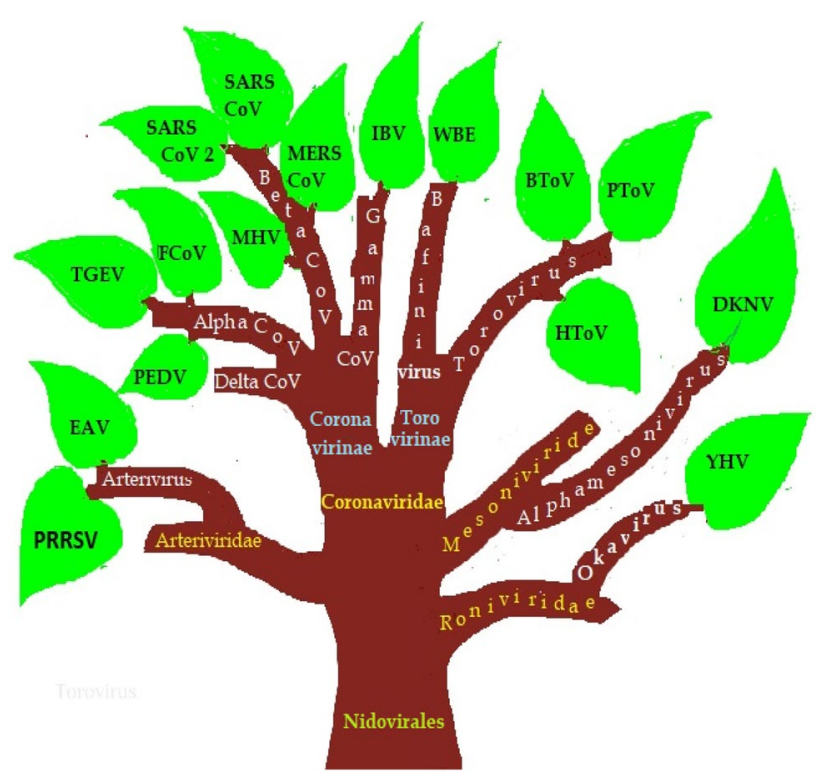

Fig. 2 Classification of the nidovirales family 
Fig. 3 Animal origins, intermediate host, and symptoms of MERS-CoV, SARS-CoV, SARS -CoV-2 human coronaviruses

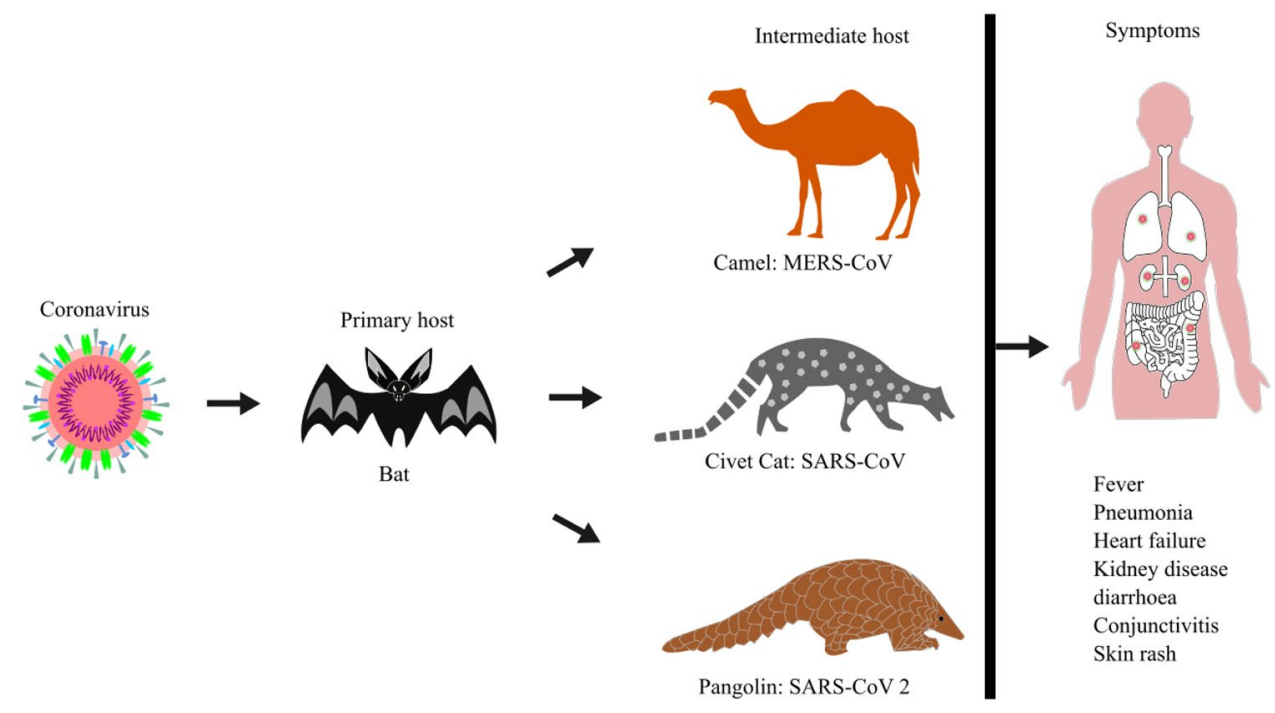

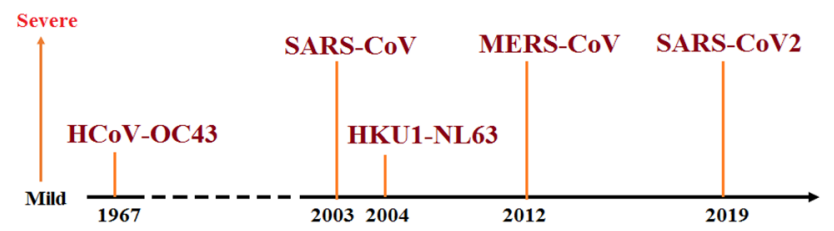

Fig. 4 Timeline of coronavirues and their relative level of severity

At the end of 2019, SARS-CoV-2 identified in humans first time in Wuhan, China, in December 2019 and is the cause of Coronavirus disease -2019 (COVID-19) (Fig. 4).

The SARS-CoV recorded around 8000 infected cases with a mortality rate of $10 \%$ in 26 countries. In contrast, MERS-CoV recorded about 2500 infected cases in 27 countries, primarily in the Middle- East, with a higher mortality rate (about 35\%) [3, 4]. The newly emerged SARS-CoV-2 has recorded greater than one hundred eighty million cases with a $2.17 \%$ global average fatality rate in more than 200 countries as of July 2, 2021 [5]. This novel human coronavirus has significantly impacted the economy and the health care systems worldwide, causing radical changes in people's everyday habits and lifestyles across continents. Basic reproduction number $\left(\mathrm{R}_{0}\right)$, case fatality rate (CFR) and incubation period are the three most common factors extensively studied in the epidemiology of diseases. A comparison of these three factors for the nine most widespread epidemics of all time have been represented in Table 1 [6-32].

SARS-CoV-2 has a unique single strain of RNA virus that causes COVID-19 with respiratory and gastrointestinal illness in both humans and animals. It can be transmitted through respiratory droplets with direct/indirect contacts and characterized by distinct medical signs and symptoms. Few incidences of gastrointestinal symptoms such as diarrhoea up to $4 \%$ [33] and some early signs of loss of smell/taste
Table 1 Basic reproduction number $\left(\mathrm{R}_{0}\right)$, case fatality rate $(\mathrm{CFR})$ and incubation period in the epidemiology of selected diseases

\begin{tabular}{lccll}
\hline Epidemic & $\mathrm{R}_{0}$ number & $\begin{array}{l}\text { Incubation } \\
\text { period (Days) }\end{array}$ & CFR (\%) & References \\
\hline SARS & $3.1-4.2$ & $1-10$ & 11 & {$[6-8]$} \\
MERS & $0.3-0.8$ & $2-14$ & 35 & {$[9-11]$} \\
COVID-19 & $0.48-6.94$ & $2-14$ & 2.17 & {$[12-17]$} \\
Ebola & $1.5-1.9$ & $2-21$ & $83-90$ & {$[10-21]$} \\
Chicken pox & $10-12$ & $14-16$ & 0.02 & {$[22-24]$} \\
Smallpox & $3.5-6$ & $7-17$ & 3 & {$[25,26]$} \\
Influenza & $0.9-2.1$ & $1-3$ & 0.1 & {$[27,28]$} \\
Measles & $12-18$ & $10-12$ & $1-3$ & {$[29,30]$} \\
Mumps & $10-12$ & $16-18$ & 1 & {$[24,31,32]$} \\
\hline
\end{tabular}

were also reported [34]. Since there is no effective medication is available against the virus, supportive treatment with repurposed drugs and broad-spectrum antibiotics, antiviral nanoparticles provide relief to the patients in many countries and some preventive strategies to block the routes of transmission of this infectious disease (Fig. 5). The major attribution is the restriction in the movement of the people, disinfection of patient handling equipment, use of personal protective equipment, early diagnosis, avoiding close contact with the diseased person, and mildly infected people were isolated in the residence or outpatient environment [35-39]. Washing hands, physical distancing, sanitization, and other practices must be followed as per the guidelines. The immune system, which can be enhanced by regular exercise and a balanced diet, reduces the virus's effect [40].

Recently, few polymeric materials have demonstrated antiviral capabilities [41-47], which can prevent or inhibit the spread of a virus by (a) providing a semipermeable barrier (e.g. a mask or face-shield), (b) interfering with binding 
Fig. 5 Preventive strategies against SARS-CoV-2 at some of the selected sources of infection
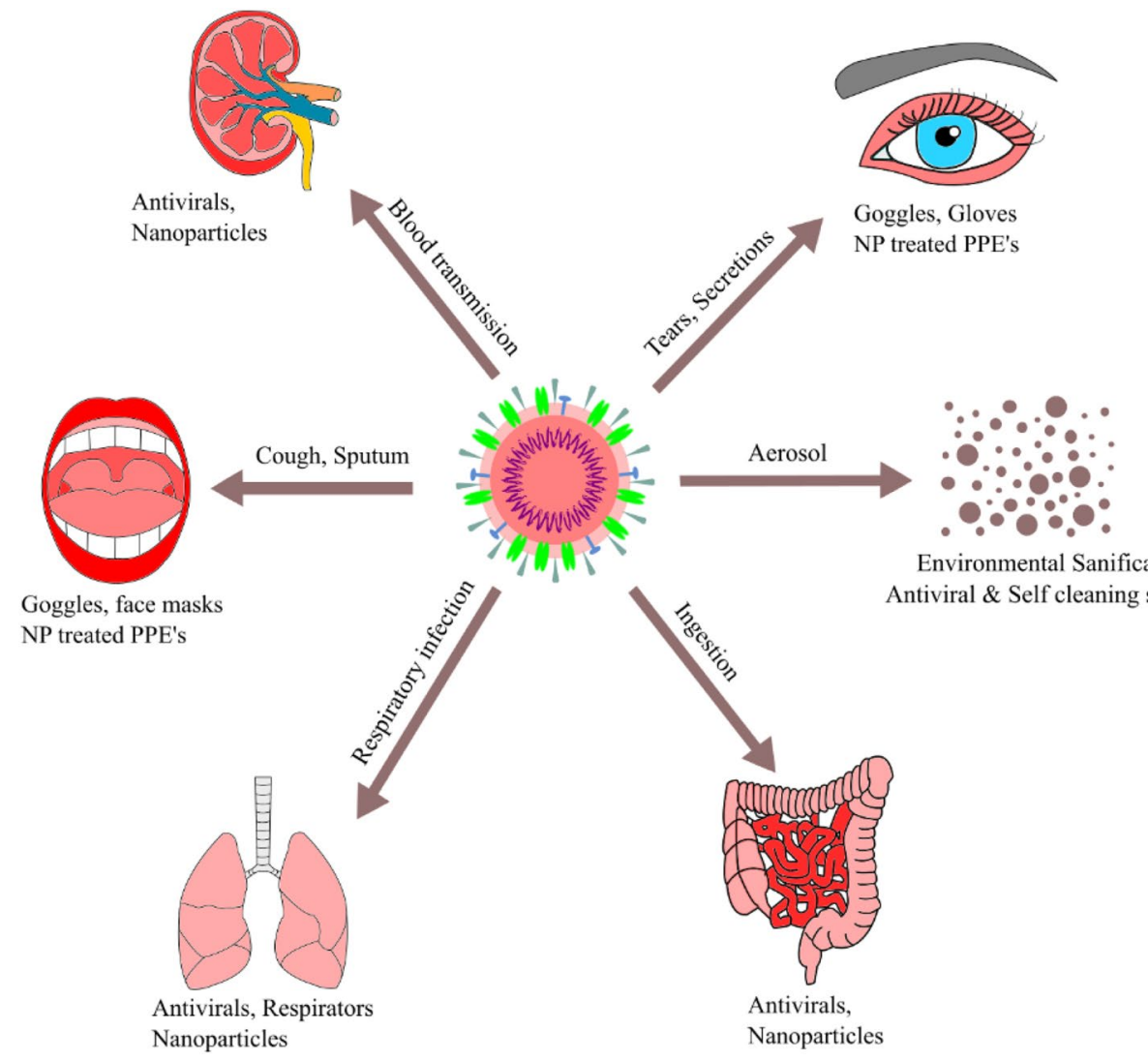

Environmental Sanification Antiviral \& Self cleaning surfaces to the glycoprotein surface of host cells, (c) augmenting small molecular antiviral drug therapies, (d) enhancing the response of the immune system as a vaccine adjuvant, or (e) as a vehicle for other therapeutic molecules to improve the water solubility or stability of antiviral therapeutics.

The objective of this review is to highlight the epidemic caused by SARS-CoV-2 and the importance of natural, synthetic or modified polymeric materials and nanoparticles that can be used to inhibit the virus entry into the cellular receptors due to its promising antiviral activities. Therefore, these materials may be utilized as an inhibitor for the deadly spreading of SARS-CoV-2. In addition, the mechanism of viruses in the human body (Fig. 6) and the mechanism of virus inhibition reported by different researchers are summarized in this review with a short perspective of the polymeric approach toward the treatment of this new type of coronavirus.

\section{Polymeric Materials}

The investigation with polymeric materials and nanoparticles $\left(\mathrm{NP}_{\mathrm{S}}\right)$ as an antiviral agent has been successfully carried out for many years, producing unique classes of materials that hold promise for conquering these hurdles. It can directly inhibit viral replication and infection, usually by binding to the virus and preventing it from invading a host cell. Both natural and synthetic polymers show the ability to be used for antiviral treatment. The natural polymers include cyclodextrin, chitosan, carrageenans, whilst the synthetic polymers are polyethyleneimine (PEI), poly (dl-lactide-coglycolide) (PLGA), dendrimers and metal and metal oxide NPs, namely silver, copper, titanium, zinc and gold, have been introduced as effective antiviral agents.

\section{Chitosan}

Chitosan is a natural linear polysaccharide composed of randomly distributed $\beta$ - $(1 \rightarrow 4)$-linked D-glucosamine (deacetylated unit) and $N$-acetyl-D-glucosamine (acetylated unit). It gained interest not only for its natural abundance but also for its unique antiviral, antibacterial, anti-inflammatory activities, biocompatibility, biodegradability, non-toxicity, and extreme moldable properties [48-53]. Thus, it has broad prospects in biomedical science and potential applications in gene therapy, material science, biotechnology, food industry, cosmetics, environmental protection, agriculture, and even wastewater treatment [54]. Chitosan is a deacetylated derivative of chitin (Fig. 7), a naturally occurring polymer in shrimp, squid, and crab shells $[55,56]$. Some of the acetamide $\left(-\mathrm{NHCOCH}_{3}\right)$ functional groups of chitin are transformed into primary amine $\left(-\mathrm{NH}_{2}\right)$ functional groups 
Fig. 6 The life cycle of SARSCoV-2 in human host cell

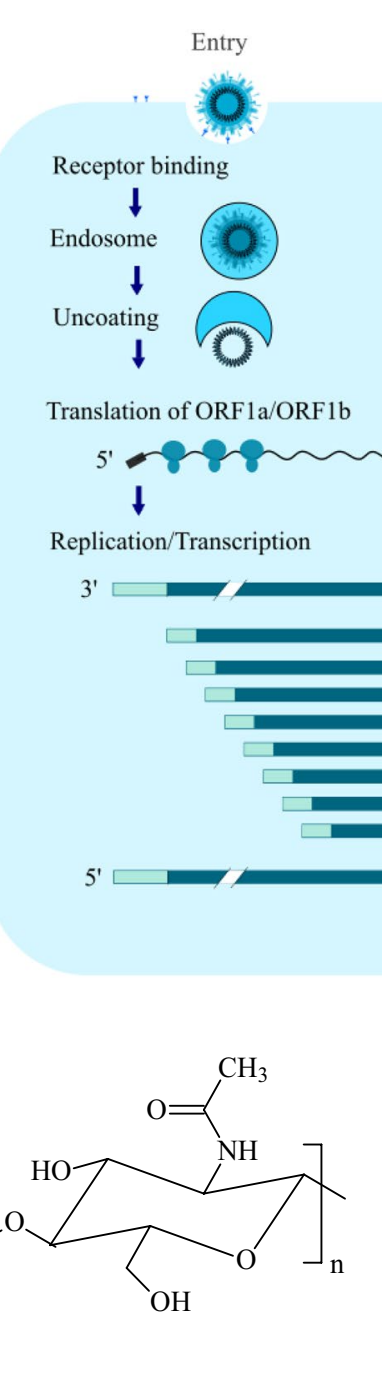

(a) Chitin

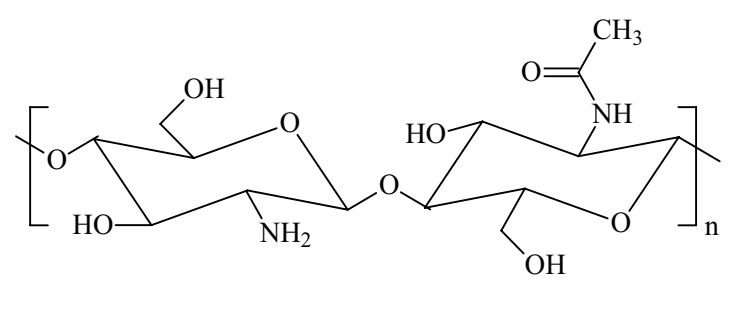

(b) Chitosan

Fig. 7 Chemical structures of chitin and chitosan

through an incomplete deacetylation process. Because of this, the glucose portion of chitosan contains a randomly distributed acetylated (-NHCOCH 3$)$ and deacetylated $-\mathrm{NH}_{2}$ groups along the chain. The ratio of 2-acetamido-2-deoxyD-glucopyranose to 2-amino-2-deoxy-D-glucopyranose structural units is known as the extent of acylation has a notable effect on chitin solubility and solution properties. Various chitosan with different degrees of acetylation (DA) have been synthesized and reported [57].

The presence of amine groups in the structures gives room for modification reactions. Thus, following the successful deacetylation of chitin to produce chitosan, biomedical researchers [58-62] made modifications to the chemical structures of chitosan to produce cationic chitosan derivatives, such as N-(2-hydroxypropyl)3-trimethylammonium chitosan chloride (HTCC)and
N-dodecyl-N-(2-hydroxypropyl)-3-trimethylammonium chitosan chloride (HM-HTCC). HTCC is formed by the reaction of chitosan with glycidyl trimethylammonium chloride, while the HTCC forms the HM-HTCC with $\mathrm{N}$-dodecyl aldehyde. Figure 8 shows the structural difference between the HTCC and HM-HTCC. Due to the random distribution of acetamide and amine groups in the chitosan chain, $-\mathrm{R}$ can be either $-\mathrm{H}$ or $-\mathrm{COCH}_{3}$. Similarly, in HM-HTCC polymer, $-\mathrm{R}$ may be $-\mathrm{H}$ or $-\mathrm{COCH}_{3}$ or $-\mathrm{C}_{12} \mathrm{H}_{25}$.

Galactosylated Chitosan (GC) hydrophilicity is higher than chitosan when the degree of galactosed chitosan decreased, which indicates that it could be used as a novel promising scaffold for hepatocyte and transplantation. GC is positively charged spherical shape particles having an average diameter of $1.05 \mathrm{~nm}$ and standard zeta potential $+15 \mathrm{mV}$. 


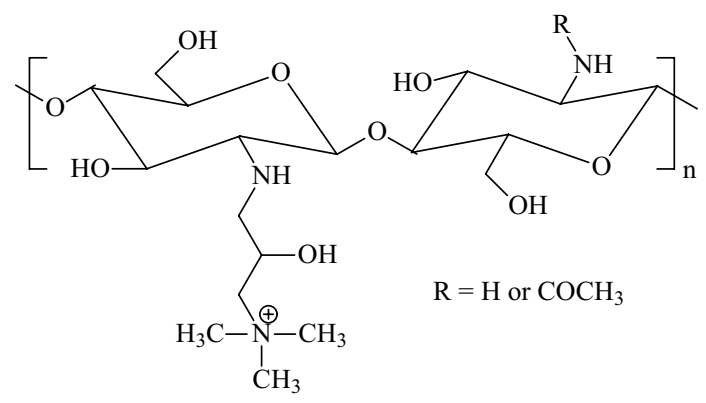

(a) HTCC

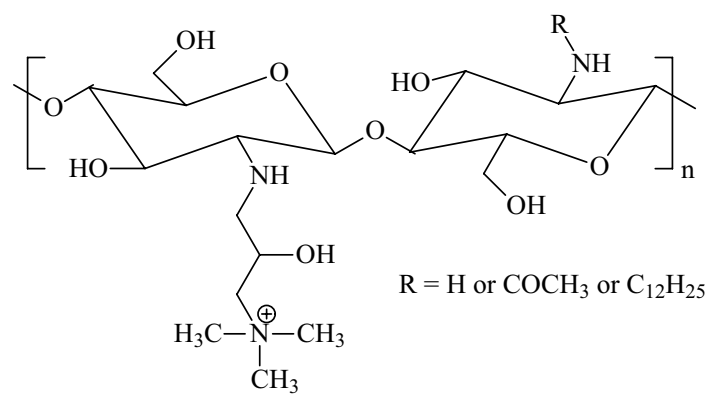

(b) HM-HTCC

Fig. 8 Chemical structures of HTCC and HM-HTCC

Due to their novel properties, GC particles can act as passive and active drug targets to the liver [63].

\section{Cyclodextrin}

Cyclodextrins (CDs) are non-toxic oligosaccharides with cyclic $\alpha$-D-glucopyranose units of $(\alpha-1,4)$-linkage, hydrophobic interior and hydrophilic exterior. Studies with CD and its derivatives show its ability to form complexes with various drugs in the last two decades. It can further enhance the solubility of water-insoluble drugs during formulations by the inclusion complexation technique. The advantages of the complexed drugs with CDs are their abundance, higher stability, masking of bad test or odor, less volatile nature, minimized side effects, and improved drug release system [64].

\section{Carrageenans}

Carrageenans (CGNs) are a family of natural high molecular weight and linear sulfated polysaccharides that are mainly extracted from marine seaweeds. These natural polymers are ionic in nature as they contain about $15-40 \%$ ester sulfate content. They are further classified into three groups based on their degree of sulfation (sulfate content), namely kappa $(\kappa)$, iota ( 1$)$ and lambda $(\lambda)$ carrageenans, containing one, two, and three negatively-charged sulfate ester groups per disaccharide repeating unit, respectively (Fig. 9). Thus, the main differences that influence the properties of $\kappa-\mathrm{CGN}$, - $-\mathrm{CGN}$, and $\lambda$-CGN are the number of the ester sulfate groups and their relative positions on the repeating galactose units. CGNs polymers of different molecular weights have been used widely to facilitate drug formulation or sustained drug release [65-70].

\section{Polyethylenimine}

Polyethylenimine (PEI) is one of the important and prominent organic polyamine polymers, also the best example of widely studied polycationic polymers. It can form nanosized particles by constructing a linkage with the sugarphosphate backbone of nucleic acids [71]. They are watersoluble, branched synthetic polymer with flexible length and frequently used in vitro and in vivo as a non-viral vector for DNA/RNA transfection and gene silencing. However, their toxicity depends on the molecular weight, and increased
Fig. 9 Chemical structure of the repeating disaccharide units in $\kappa$-CGN, $\mathrm{l}$-CGN, and $\lambda$-CGN

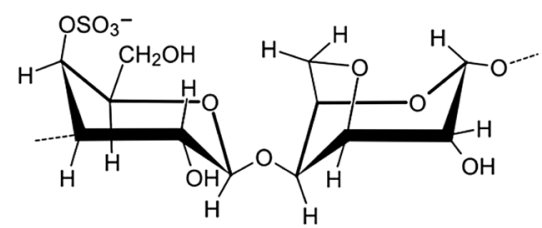

kappa $(\kappa)$

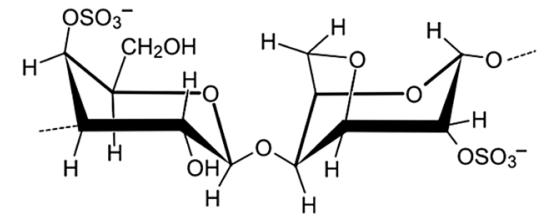

iota (1)

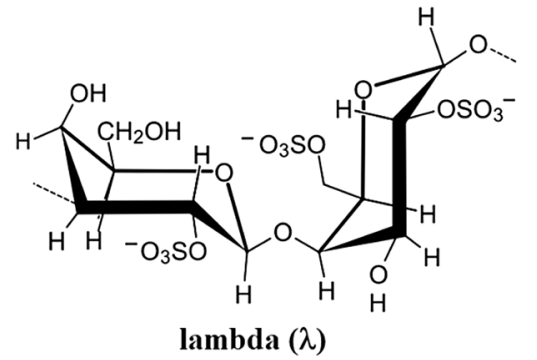


branching and higher charge density restrict its usage in human gene therapy [72]. Hence several methods such as covalent binding of polyethylene glycol or several moieties with PEI were used to increase its stability and reduce toxicity [73]. Modifications of PEI using a coating of serum albumin [74], dextran [75], acylation [76] led to enhance the biocompatibility and gene transfer efficiency.

\section{Poly (lactic-co-glycolic acid)}

Poly(lactic-co-glycolide) (PLGA) is a well-established biodegradable polymer used in medical devices and drug delivery applications. They are less toxic compared to cationic polymers. By varying the quantity of $\mathrm{D}, \mathrm{L}$ lactide and glycolide, different forms of PLGA can be obtained [77].

\section{Dendrimers}

Dendrimers are highly branched three-dimensional macromolecules with nano-size dimensions and distinctive properties due to their spherical shape and internal empty core space. The empty internal cavity can encase other molecules into its macromolecular cavity and act as coating and prevent those molecules from further oxidation and clustering. These unique properties of dendrimers made them useful as diagnostic agents, antibacterial, antitumor, and biomedical applications $[78,79]$. Dendrimers have a definite branched structure with the presence of different compositions and groups included a large surface area in its moiety made a unique spherical shape. These groups can be considered the active functional sites that provide a template for drug immobilization and grafting. The center core of the dendrimer consists of an atom or multifunctional molecule, and branching units form a covalent bond with the central core and terminal functional groups on the external surface. Dendrimers are monodispersing macromolecular units with specific sizes and molecular mass. Due to their reproducible shape and size, they have well-controlled rheological properties. The terminal groups of dendrimers can be controlled to have distinct properties like hydrophilicity or lipophilicity, solubility, miscibility, and acidity. One of the most important features of dendrimers is the ability to encapsulate small size materials such as drugs, metals, and imaging moieties that can fit within their cavities and interact through charge interactions, hydrogen bonding, and lipophilicity. The encapsulation of drugs in dendrimers can increase drug stability, reduce possible drug toxicity, and expedite the drug's targeted and controlled release. Dendrimers are a low-cost base compared to proteins with higher biocompatibility and provide an accurately controlled large macromolecular surface [80]. The dendrimers can encapsulate other biologically active compounds and conjugate molecules, and act as a coating [81]. For each generation of a dendrimer, the number of surface groups rises exponentially while the diameter increases linearly. In addition, the introduction of varied chemical groups such as basic, acidic, hydrophobic, hydrogen-bonding capability, and charges, allows modification and controlling of the chemical properties and architecture of core, branches, and surface groups of dendrimers [82]. These variation of the properties, composition and architecture of dendrimers are the key physicochemical properties that improve theirs in vitro [83] and in vivo [84] behaviours.

G4 -PAMAM (poly amidoamine)dendrimer amine-terminated PAMAM dendrimer used as a coating for the nano $\mathrm{Ni}$ material- $\mathrm{Ni}\left(\mathrm{NO}_{3}\right)_{2} \cdot 6 \mathrm{H}_{2} \mathrm{O}$, which can exhibit good antimicrobial activity against various bacteria [78]. The nano Ni material usually undergoes rapid oxidation and aggregate during ambient conditions. Dendrimer can encapsulate Ni NPs and act as a coating to prevent them from further oxidation and aggregation. The chemical reaction exhibited by this dendrimer encapsulated Ni nanoparticles prevent bacterial growth by disrupting the cell wall when it was tested against E coli bacteria [85].

\section{Polymeric Nanoparticles (NPs)}

NPs based polymers are widely used in medicine as gene carriers. They are colloidal solids with a particle size of $10-100 \mathrm{~nm}$. Due to their very small size, they can do capillary intrusion and absorption by cells, which results in higher concentrations at the target site [86]. Their unique properties such as lower particle size [87], higher surface area to volume ratios [88], tunable surface charge [89], biomimetic properties [90,91], and the possibility of drug encapsulation [92] help them to be used as a weapon against virus treatment. However, their antiviral properties have been investigated and used for development or improvement purposes only for some viruses like influenza, HIV, and rabies [93, 94]. The metal and metal oxide-based nanoparticles can work as attachment blocking, reproduction inhibitory action, and viral wall and membrane deformation [95].

\section{Mechanism of Inhibition of Viruses}

SARS-CoV-2 has caused a worldwide health crisis due to its high infection rate. Several preventive strategies have been adopted to combat this lethal infection include facemask use, vaccine development, repurposed antiviral drugs, and macromolecular neutralizing antibodies [96, 97]. Polymeric materials have been designed as antiviral inhibitors and drug delivery carriers for effective virus inhibition and antiviral drug delivery carriers. It includes natural and synthetic polymeric materials, polymer-based prodrugs, nanoparticles, which show the potential and significantly improve 
the efficacy of antiviral therapeutic strategies (Table 2 [58, 98-105] and Table 3) [106-131].

\section{Chitosan}

Generally, antiviral polymeric drugs have been developed mainly based on the inhibition of the virus's interactions with the host cell. Polymers used their high molecular weight and multivalent binding capability to exert their antiviral activity through steric shielding of the viral surface or competitive inhibition of the interactions [132]. The blocking of host cell receptor from viral docking and entry can be achieved either via polymer binding to the host cell or the virus, both of which leads to a reduction in viral entry (Fig. 10). HTCC polymers with different degrees of substitution have been reported to have an antiviral activity used to treat infections caused by coronaviruses by inhibiting viral replication. Milewska and his co-workers used functional assays, molecular methods, flow cytometry, and confocal microscopy to study the mechanism of HTCC antiviral activity against human coronaviruses [58, 133, 134]. Even though the HTCC polymers do not hamper virus binding to heparan sulfate proteoglycans (HSPs), the polymers interact with the corona viral spike protein and block virus interaction with cellular receptors ACE2 proteins. Recently, the antiviral activity against the pathogenic SARS-COV-2 and MERS-COV using permissive cell lines and human airway epithelium model for in-vitro and ex-vivo, respectively [135]. The result revealed that HTCC efficiently blocked replication of both SARS-COV-2 and MERS-COV. Thus, HTCC polymers with different degrees of substitution are considered potent inhibitors and promising drug candidates for the highly pathogenic SARS-COV-2. HTCC with varying degrees of substitution has a different inhibitory effect on coronaviruses. Though the degree of substitution in HTCC polymers is usually varied between 57 to $77 \%$, different HTCC polymers have different inhibitory of coronaviruses. Table 4 summarizes the HTCC polymers that have the most significant inhibitory effect on different coronaviruses [58, 133-135].

\section{Cyclodextrin}

The cavity in the CDs allows the encapsulation of hydrophobic groups forming inclusion complexes without modifying the guest's structure and chemical properties [136]. Alternative interaction mechanisms such as forming non-inclusion complexes or the solubilization through aggregates can also be present in CD solutions. Sun et al. [137] discussed the mechanism and production of CD-soluble angiotensinconverting enzyme 2 (CD-sACE2) inclusion compounds treatment of SARS-CoV-2 infections by blocking S proteins. sACE2, the extracellular region of ACE2, retains the enzyme activity of ACE2 and can bind to the S-protein of SARS-CoV, inhibiting SARS-CoV infected cells. Since the infection mechanism of SARS-CoV and SARS-CoV-2 is the same, sACE2 could also inhibit the infection of SARS$\mathrm{CoV}-2$. The formation of a complex of $\mathrm{CD}$ and sACE2 could effectively improve the water solubility of sACE2, so it meets the requirements for drug atomization inhalation. The inclusion conjugates release sACE2 after entering the body via atomization or other drug delivery. The released sACE2 would combine with SARS-CoV-2 S-proteins to block the virus's ability to infect and destroy human cells.

\section{Carrageenans}

Carrageenans exhibit antiviral activity against African swine fever virus, rhinovirus, influenza A virus enterovirus, human herpes, and dengue virus [65-70, 138]. Very recently, Yejin and his co-workers [102] investigated the efficacy of the sulfated polysaccharide CGN against SARS-CoV-2 spike antibody, and the immunofluorescence microscopy result revealed that $\lambda$-CGNs effectively inhibit the SARS-CoV-2 viral infection without the viability of the cell. Moakes and his coworkers [139] recently reported the nasal formulations actively target the removal of SARS-CoV-2. In addition, the spray system, which is a composite mixture containing both gellan and $\lambda$-CGNs, has been reported to demonstrate highly potent capacities against SARS-CoV-2 infection in Vero cells, resulting in complete inhibition of the virus. While the gellan systems exhibited limited ability to suppress the SARS-CoV-2 virus, the $\lambda$-CGN showed complete inhibition of the SARS-CoV-2 infection over $48 \mathrm{~h}$. However, the highly potent antiviral composite system provided an enhanced mechanical response towards spraying and antiviral activity, a synergistic behaviour from both gellan and $\lambda$-CGN. Thus, the spray's ability to completely inhibit viral infection is attributed to the active polysaccharide $\lambda$-CGN component of the spray formulation. The mechanism for the inhibition of the SARS-CoV-2 virus from attacking the host cell receptors is assumed to be either through the creation of a steric barrier across the host cell or around the virus interface, as illustrated in Fig. 11.

\section{Polyethylenimine}

The polycationic polymer such as $\mathrm{N}, \mathrm{N}$-dodecyl methylpolyethyleneimine (PEI), can act as a good antiviral agent towards hydrophobic glycoprotein SARS-CoV-2 as reported in the case of the influenza virus, which was protected from the outside by a lipid membrane. Different solid surfaces such as glass, polypropylene, and polyethylene modified with hydrophobic polycationic polymers produce strong surface-protein interaction caused the viral protein loss destroying the virus [140]. However, it has been reported 


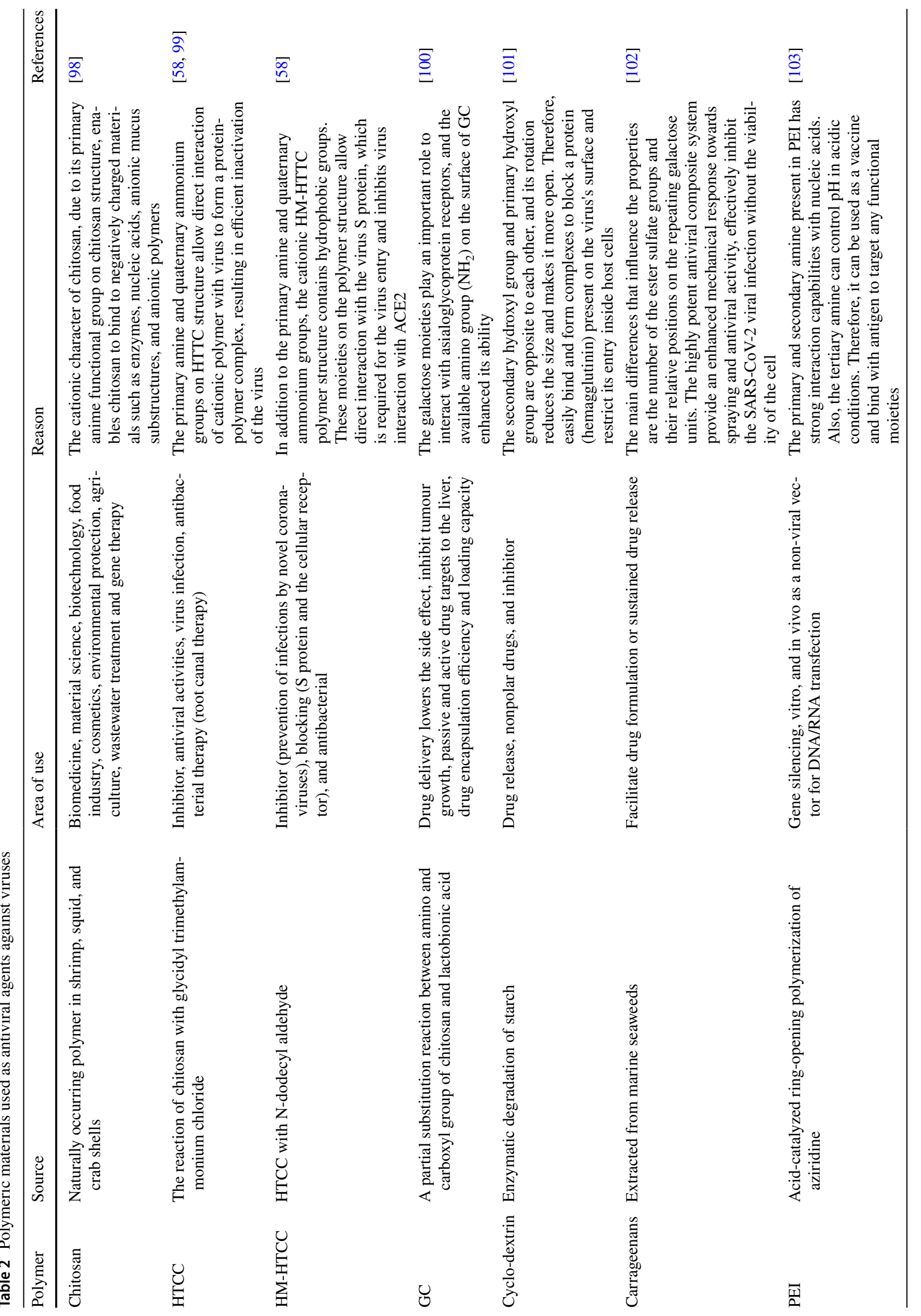




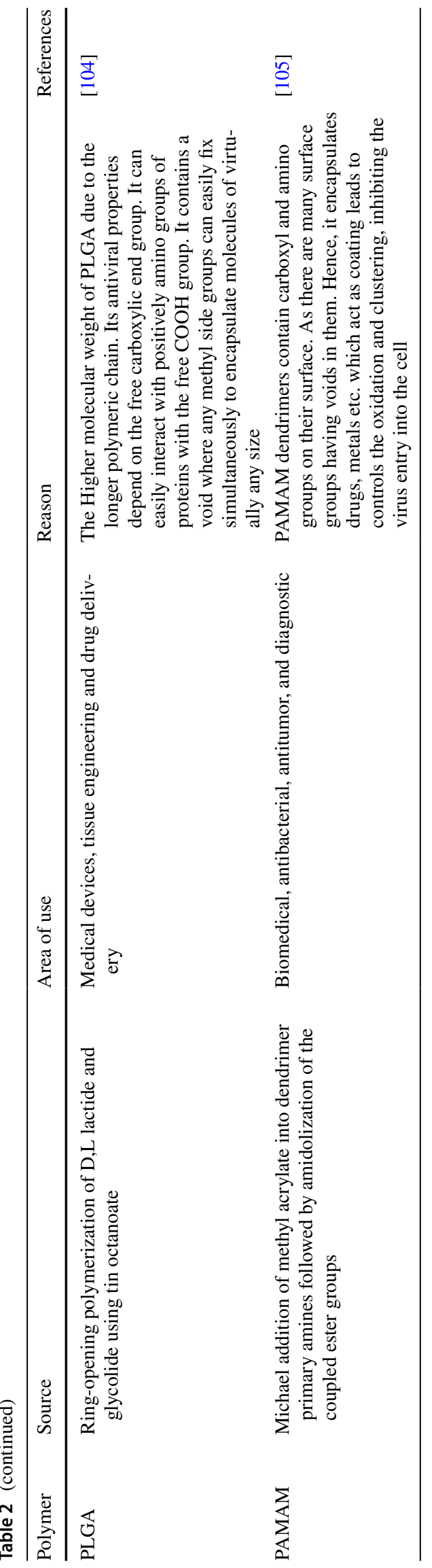

that modified surfaces of polypropylene and polytetrafluoroethylene with hybrid self-assembled monolayers (SAMs) have enhanced binding with spike proteins, eventually disintegrate the coronaviruses [141].

\section{Poly (lactic-co-glycolic acid)/Poly (lactic-co-glycolide) (PLGA) and PLGA NPs}

PLGA is a well-established, less toxic biodegradable synthetic copolymer used in FDA-approved pharmaceutical products and medical devices. NPs developed by polymeric materials such as PLGA, PLA, poly(ethylene glycol)-poly(ecaprolactone) (PEG-PCL), and PLA-PEG have been used as nanocarriers drug delivery systems for the antiviral disease treatment [142]. PLGA NPs have been shown preclinical efficacy in antigen vaccines technology like HBs Ag, Malaria antigens, Bacillus anthracis spores to generate extended cellular and humoral immune response as suitable candidates for encapsulating the antigens within the nanocarrier to provide extended and controlled biological release [143].

\section{Dendrimer}

Polymeric materials comprising dendrimers such as polyamidoamine (PAMAM), PAMAM (EDA), and polylysine dendrimers have been reported to have a significant antiviral effect against enveloped viruses, including the human immunodeficiency virus [144]. Anionic dendrimers including hydroxyl, carboxyl, and succinic-acid terminated PAMAM and cationic dendrimers containing primary amine end groups exhibit significant antiviral activity with MERSCoV [145]. Nontoxic nanogel based polyglycerol sulfate dendrimer showed extensive antiviral activities by inhibiting viruses from binding to the cellular surfaces. Heparan sulfate also acts as a co-receptor for SARS-CoV-2 mediating entry to host cells. Therefore, nanogel based dendrimers could be a potential component in COVID-19 therapy [146, 147].

\section{Polymeric Nanoparticles}

Metal-based NPs have a higher surface area, enhancing the exclusive physicochemical properties that allow them to intermingle with viruses and other micro-organisms. The function of metal-based nanoparticles antivirals includes three interacting stages, (a) linking and connecting with the virus to inhibit the virus attachment penetration into the cell; (b) generating highly active oxygen, other ions and radicals that adhere to the wall (spikes or membrane) and able to destroy the structure and its function of viral proteins and nucleic acids; (c) simulating the nucleus to enhance the immune response of the host cell, and preventing the virus's budding and spreading. 
Table 3 Polymeric nanoparticle-based approach for viral inhibition and diagnosis

\begin{tabular}{|c|c|c|c|}
\hline Nanoparticles & Mechanism of Antiviral Action & Purpose & Reference \\
\hline \multirow[t]{5}{*}{ AgNPs } & $\begin{array}{l}\text { Inhibit the virus binding with the cells in } \\
\text { the initial stage of virus life cycles }\end{array}$ & $\begin{array}{l}\text { Inactivate replication and minimize viru- } \\
\text { cidal activity }\end{array}$ & [106] \\
\hline & $\begin{array}{l}\text { Restrict structural change due to viral inva- } \\
\text { sion in the entry cell }\end{array}$ & $\begin{array}{l}\text { Stop replication and act as an antiviral } \\
\text { agent }\end{array}$ & [107] \\
\hline & $\begin{array}{l}\text { It blocked to form } \mathrm{CD}^{+} \mathrm{T} \text { cells through } \\
\mathrm{CD} 4 \text { binding with present gp120 on the } \\
\text { surface envelope glycoprotein }\end{array}$ & $\begin{array}{l}\text { Replication of virus entry into the target } \\
\text { cell }\end{array}$ & {$[108]$} \\
\hline & Control viral culture & Prevents non-envelope viruses entry & [109] \\
\hline & $\begin{array}{l}\text { Produce electrospun coating to stop inter- } \\
\text { action with the viral surface }\end{array}$ & $\begin{array}{l}\text { Reduce virus reproduction during entry } \\
\text { into the cell }\end{array}$ & {$[110]$} \\
\hline Ricinus Communis AgNPs & $\begin{array}{l}\text { Viral fusion between envelope protein and } \\
\text { host cell }\end{array}$ & Anti-enterovirus agent & [111] \\
\hline Fungi-AgNPs & $\begin{array}{l}\text { Minimize virus infection and stop interac- } \\
\text { tion of the virus with the host cell }\end{array}$ & Antimicrobial agent & [112] \\
\hline Cinnamon-AgNPs & $\begin{array}{l}\text { Inhibit virus propagation and blocked } \\
\text { hemagglutinin function }\end{array}$ & Restrict virus penetration inside the cell & [113] \\
\hline Coffee and green tea-AgNPs & $\begin{array}{l}\text { Destroy the viral genome organism } \\
\text { morphology and restrict hemagglutinin } \\
\text { function }\end{array}$ & $\begin{array}{l}\text { Viral replication and functioning as a } \\
\text { viricidal agent }\end{array}$ & [114] \\
\hline AgNps immobilized onto textile fabrics & Stop virus surface passivation & Act as a virucidal agent & [115] \\
\hline $\mathrm{TiO}_{2} \sim$ DNA nanocomposites & Produce nucleic acid precipitation & Inhibit virus reproduction in cell culture & [116] \\
\hline $\mathrm{TiO}_{2} \mathrm{NPs}$ & $\begin{array}{l}\text { Affect and control transport into the sub- } \\
\text { surface of virus }\end{array}$ & Inactivate the virus entry & [117] \\
\hline Silica-NPs & $\begin{array}{l}\text { Enable to detect antigen and enhance } \\
\text { blood safety by minimizing antibody }\end{array}$ & $\begin{array}{l}\text { Infection detection and adopted to obtain } \\
\text { detection range antigen of viruses }\end{array}$ & [118] \\
\hline$\beta$-cyclodextrin-graphene oxidecomposite & $\begin{array}{l}\text { Initially stop the function of virus and } \\
\text { blocked its attachment with the host cell }\end{array}$ & $\begin{array}{l}\text { Protect and enhanced healing ability } \\
\text { against the virus }\end{array}$ & [119] \\
\hline Carbon dots & $\begin{array}{l}\text { It prevents to make any linkage between } \\
\text { virus and histo-blood group antigen, } \\
\text { mostly with saliva secretor of the host } \\
\text { cell }\end{array}$ & $\begin{array}{l}\text { Control the degradation of capsid proteins } \\
\text { of the virus and slightly blocked to bind } \\
\text { with the antibody }\end{array}$ & [120] \\
\hline Protein NPs & Maintained hemagglutinin function & $\begin{array}{l}\text { It leads to activate an enhanced immune } \\
\text { response against the virus }\end{array}$ & {$[121]$} \\
\hline Polypeptide NPs & $\begin{array}{l}\text { Reduction of cell protected by } \mathrm{CD} 4^{+} \mathrm{T} \\
\text { cells and transfusion provide immune } \\
\text { serum }\end{array}$ & Lifetime immune response & {$[122]$} \\
\hline Polystyrene NPs & Mannose-specific lectin & Mucosal vaccine & [123] \\
\hline PVP-stearic acid-polyethylene glycol -NPs & Enhanced endocytosis pathways & Anti-viral agents & [124] \\
\hline Magnetic NPs & $\begin{array}{l}\text { Virus detected through different quantifi- } \\
\text { cation methods }\end{array}$ & $\begin{array}{l}\text { Treatments and diagnosis of the infected } \\
\text { cells }\end{array}$ & {$[125]$} \\
\hline POD-NLCs & Controlled cell proliferation & Anti-viral agents & [126] \\
\hline Dendrimer-RNA NPs & $\begin{array}{l}\text { Enhanced } \mathrm{CD}^{+} \mathrm{T} \text { cells on the surface of } \\
\text { envelope glycoprotein to work against } \\
\text { IgG responses }\end{array}$ & $\begin{array}{l}\text { Detection of antigen and vaccine prepara- } \\
\text { tion }\end{array}$ & {$[127]$} \\
\hline $\begin{array}{l}\text { G2-dendrimer-citric acid-polyethylene } \\
\text { glycol }\end{array}$ & $\begin{array}{l}\text { Antibody neutralization and boost immune } \\
\text { response }\end{array}$ & Vaccine technology & [128] \\
\hline \multirow[t]{3}{*}{ AuNPs } & $\begin{array}{l}\text { Inhibit hemagglutinin function and pro- } \\
\text { duce antibody-protein antigens }\end{array}$ & $\begin{array}{l}\text { Enhanced immunity response and cell } \\
\text { protection against virus }\end{array}$ & [129] \\
\hline & $\begin{array}{l}\text { Useful to generate an antibody that can be } \\
\text { bind with the membrane matrix protein } \\
\text { of the infected cells }\end{array}$ & $\begin{array}{l}\text { Preparation of vaccine and as viricidal } \\
\text { agents }\end{array}$ & [130] \\
\hline & $\begin{array}{l}\text { Detection of virus pathogen by incorporat- } \\
\text { ing a specific antibody }\end{array}$ & Applied as an immunosensor & {$[131]$} \\
\hline
\end{tabular}


Fig.10 Mechanism of blocking of host cell receptor from viral docking and entry by antiviral polymeric drugs

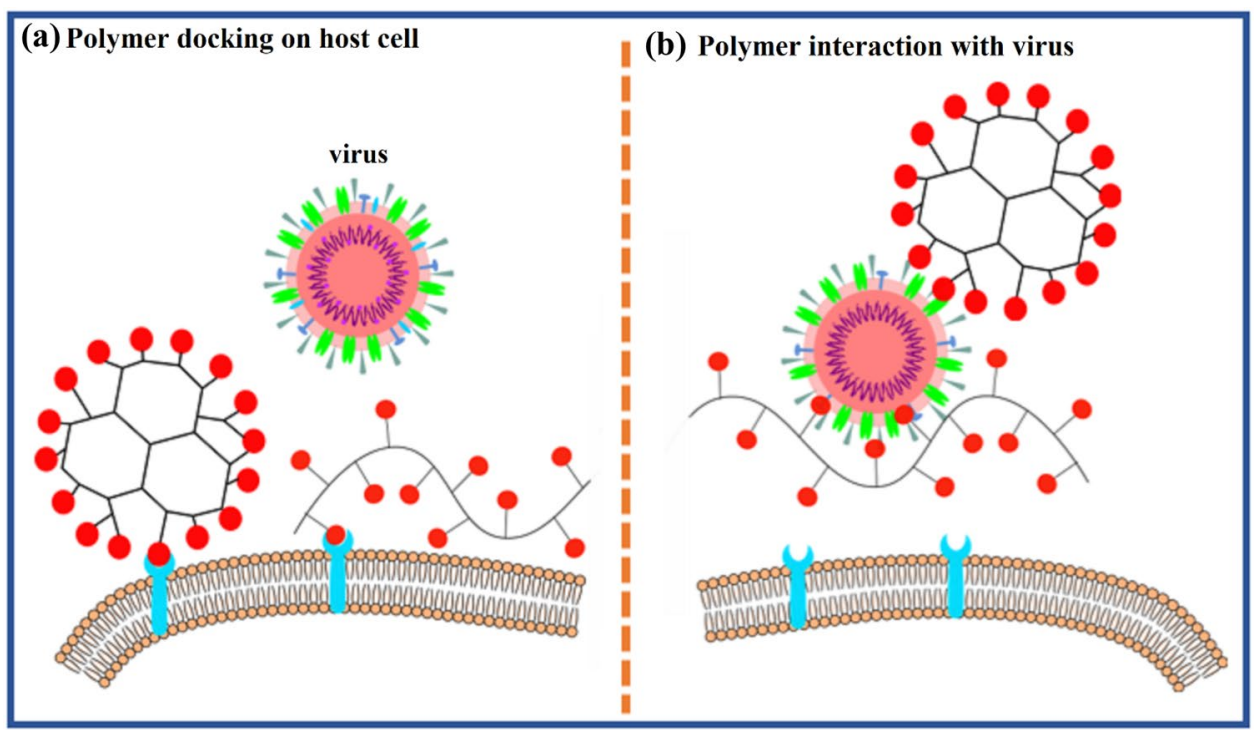

Table 4 Coronaviruses that are significantly inhibited by HTCC polymers

\begin{tabular}{lll}
\hline Polymer & Degree of substitution* (\%) & Coronavirus \\
\hline HTCC-63 & 63 & HCoV-NL63, \\
& & HCoV-OC43 \\
HCoV-HKU1 \\
MERS-CoV \\
HTCC-62 & \multirow{2}{*}{63} & HCoV-229E \\
& & HCoV-HKU1 \\
HTCC-65 & 65 & HCoV-NL63 \\
& & HCoV-OC43 \\
HTCC-77 & 77 & HCoV-229E \\
& & SARS-CoV-2 \\
\hline
\end{tabular}

*The fraction of amine group $\left(\mathrm{NH}_{2}\right)$ substituted within the chitosan chain

\section{Silver-Based Antiviral Nanoparticles}

Silver and its derivatives are classic antimicrobial compounds and in high demand for their impressive anti-pathogen performance. Silver nanoparticles (AgNPs) can interact with the outer layers of the virus and prevent their attachment on and penetration into the host cells. The average particle size of AgNPs is a crucial factor that affects their antiviral ability. Silver-based nanoparticles are classic antimicrobial compounds since they can work against pathogens efficiently. The average particle size of nanoparticles can affect their antiviral ability. They interact with the outer layers of the virus and prevent their attachment on and penetration into the host cells. Krzyzowska et al. [148] reported that Ag NPs could effectively control the herpes simplex virus type 2 (HSV-2) infection in mice by inhibiting the adhesion of the virus to host cells. Here, the silver nanoparticles quickly contact polioviruses $(25-30 \mathrm{~nm})$, destroy their
Fig. 11 Mechanism for the inhibition of SARS-CoV-2 through blockage of virus entry into the host cells as the polymer creates a steric barrier across the cell interface (a) and around the virus interface (b). Adapted from reference [134]
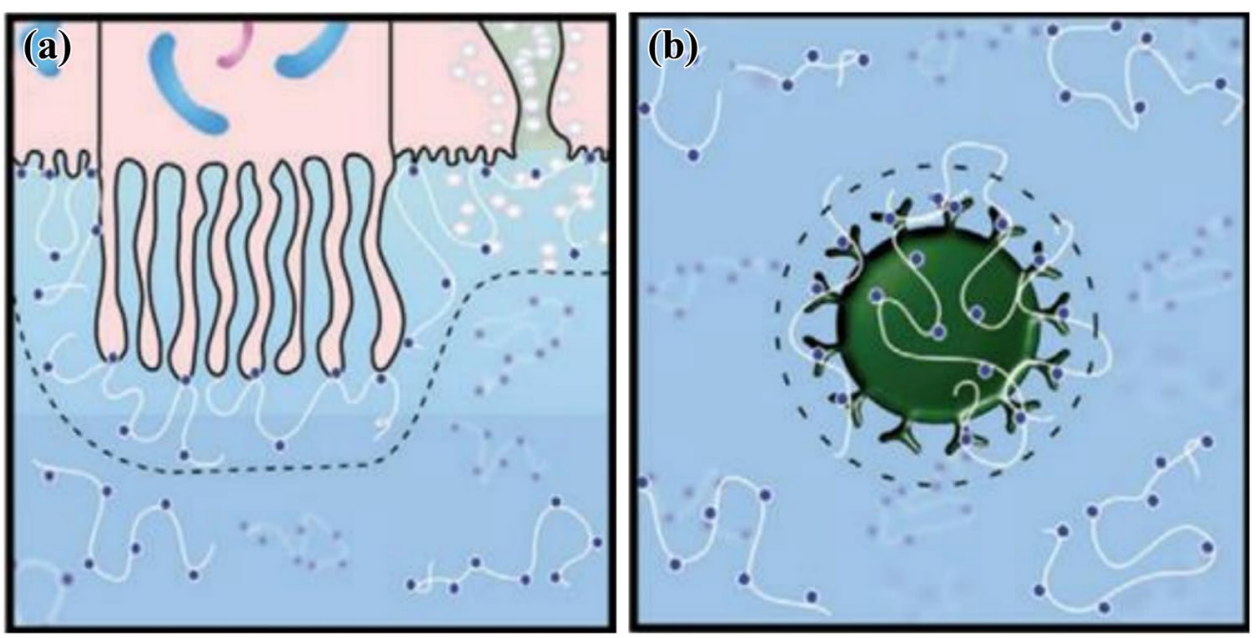
proteins molecules, and prevent them from binding with the host cells. Han et al. [149] reported that for other silver nanoparticles $\left(\mathrm{Ag}_{2} \mathrm{~S}\right)$, the antiviral activity is mainly ruled out by inhibiting RNA synthesis and viral budding. It was also argued that activating ISG proteins and pro-inflammatory cytokines might be an essential factor in this case.

\section{Copper-Based Nanoparticles}

Copper oxide nanoparticles are widely used to prepare antibacterial materials due to their low cost, higher stability, and wide range of antibacterial properties. The proposed mechanism by Tavakoli et al. [150] is as follows: the $\mathrm{Cu}^{2+}$ ions released from the nanoparticles enhances the formation of reactive oxygen species, which helps to collapse the HSV capsid integrity and degrade the whole genome. Also, nanoparticles of $\mathrm{Cu}_{2} \mathrm{O}$ having size $(\sim 50 \mathrm{~nm})$ inhibits the $\mathrm{HCV}$ viruses to be attached to the cells through the multivalent binding of virions, thereby blocking the entry of the virus into the cell [151].

\section{Gold-Based Nanoparticles}

Gold nanoparticles (Au NPs) are biocompatible and possessing the ability to bind with biological ligands [152]. Generally, the mechanism of viral inhibition by Au NPs are based on blocking the viral particles to be bound to the cell, thereby inhibiting virus attachment/entry and controlling the cell to- cell spread of the virus. Studies show that morphologies of Au NPs have eater influence on antiviral properties and mechanisms [153-155].

\section{Nanoparticles Applied to Viral RNA Extraction}

Generally, extraction based on the column is not easy in automation. The advantage of this method is that the centrifugation is not included; therefore, it allows complete automated purification of nucleic acid, which was one of the parameters for SARS-CoV-2 diagnosis. Hence an automated extraction procedure was developed based on pcMNPs for viral RNA. A system consisting of magnetic rods was introduced for the purification of nucleic acid. An automated instrumental program was fixed as per the usual protocol. No further dissociation or removal of pcMNPs takes place in the extraction process even though the shaking speed of magnetic rods were at its maximum. The solution obtained was transparent and colorless. The method based on pcMNPs was highly advantageous and suitable, as discussed earlier in viral RNA extraction. The amplification curve of manually performed samples with direct RT-PCR was similar to positive control. The efficiency and working suitability of the pcMNPs-based method to identify and separate the nucleocapsid $(\mathrm{N})$ gene originated. The outcomes proved again higher extraction efficiency of the automation method based on pcMNPs for manual and direct RT-PCR protocol with the help of ORFlab region and $\mathrm{N}$ gene assays.

The direct and straightforward RT-PCR protocols and N gene pseudovirus were compared with the modern and latest pcMNPs-based viral RNA process, which was more accurate and dynamic in the detection process. Standard fresh samples were prepared by 10 -fold serial dilution to obtain copies of pseudovirus105-10in serum along with reference samples without pseudovirus, which can be used as a negative control to detect false-positive signals. The correlation coefficient $\left(R^{2}\right)$ was higher, about 0.999 , between pseudovirus particle numbers (in logarithm) and cycle threshold $(\mathrm{Ct})$ in the range of 10 to $10^{5}$ copies. Similar results were also observed with experiments conducted by the direct RT-PCR method based on pcMNPs. The RT-PCR amplification is much more accurate for both with or without pcMNPs as per the resultant data. The amplification signals from negative control were less respectful to $\mathrm{Ct}$ but considered as valid positive results. Due to this drawback, it was mandatory to verify and optimize the primer pairs and probe. The PCR amplification and extraction efficiency were found better with the latest developed MB-based method. It concluded that RT-PCR assay even works more accurately with 10 copies of SARSCoV-2 [156].

The biosensor based on nanoparticles (NBS) was combined with reverse transcription loop-mediated isothermal amplification (RT-LAMP), developed one step, and one tube RT-LAMP-NBS assay product for diagnosis COVID-19. The target sequences, F1ab and nucleoprotein gene (np), were amplified and identified in the test simultaneously with a constant temperature. It was necessary to optimize all the required parameters and their suitability to discuss the principle of RT-LAMP for COVID-19. The RT-LAMP-NBS assay was an almost equipment-free station, strengthening the laboratory system resources and reporting the results after diagnosis. RT-LAMP-NBS assay was low cost, feasible and sensitive for detection of SARS-CoV-2 [157]. So, it became a valuable diagnostic tool used in the field and a primary health care hospital. The design of COVID-19 diagnostics was the flexible modification of the existing diagnostic technologies.

The previous experience of the 2002 SARS outbreak made the researcher more cautious in taking the right decision, which enabled the diagnostics of this virus earlier. Its optimization process was quicker, which lead to a controlled spread of it. Furthermore, with the help of electron microscopy, the study of the virus became clearer. To design PCR primers and probes, the sequencing of the genome and the morphology of the virus were the required parameters. This technology was used to identify SARS-CoV-2 for less than one month, whereas the same detection took almost 5 months for SARS-CoV. Due to this technology, nucleic 
acid tests lead to the detection and sequencing of SARSCoV-2. This type of action leads to control of the outbreak. Serological tests are the secondhand approach for testing this infection, which was more easily monitored than the nucleic acid test. Amplification at a constant temperature, barcoding, microfluidic technologies should be updated to be applied quickly for this situation. The latest technology of smartphones and diagnostics provides the highest surveillance and smooth communication of the latest updates. It was now clear that diagnostics were essential for reducing the mortality and further spread of pathogens [157]. The health worker dealt with diagnostic patients in different modes compared to others (Fig. 12).

\section{Carbon-Based Antiviral Materials}

Carbon atoms can link to each other and form allotropes such as carbon dots, carbon nanotubes and graphene oxide.
Here also the geometry of the carbon materials determines their anti-infection performance. Using carbon dots, Han et al. [158] demonstrated that the cells treated with CDs could stop the multiplication of pseudorabies virus (PRV) and respiratory syndrome virus (PRRSV) by the production of interferon-a (IFN-a) and IFN-stimulating genes (ISGs). Similarly, the GO and rGO [159] exhibited fascinating antiviral behaviours from their unique single-layer structure and surfaced negative charges. The negatively charged GO showed a higher potential to electrostatically interact with the viruses before entering the cell, ending in the destruction of its single-layer structure and sharp edges. However, the mechanism of antiviral activity in GO remains controversial.
Fig. 12 Example of the patient and sample workflow when a symptomatic patient presents himself at the hospital for triage, patients are managed based on the severity of symptoms, the collected samples are tested onsite if possible or transported for research at designated laboratories, the RNA is extracted by nucleic acid extraction and are amplified for detection by PCR (polymerase chain reaction), and graphs are analyzed to segregate positive and negative cases

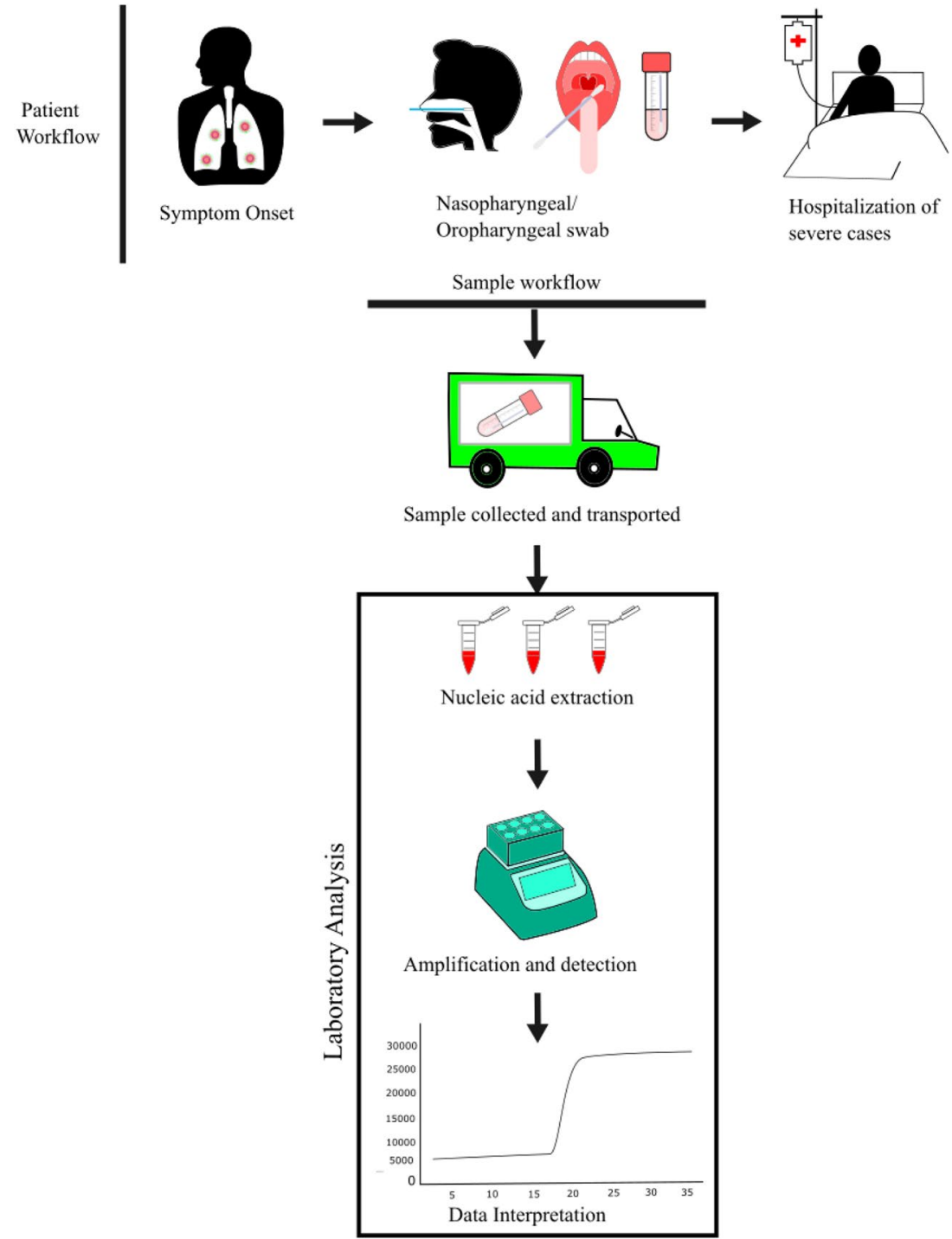




\section{Conclusion and Future Recommendations}

Chitosan-based polymers and other polymeric materials such as CD, PEI, PLGA and PAMAM dendrimer have been used to treat and prevent infections caused by coronaviruses through inhibition of their replication. Following the recent outbreak of novel coronavirus (COVID-19), these polymers could be investigated as potential antiviral agents to treat this deadly virus as few have shown inhibitory effects. The natural and synthetic polymeric materials covered in this review are biocompatible, cost-effective, environmentally friendly, and much safer for antiviral applications, detection, and inhibition. On the other hand, nanoparticles mentioned in this review are used to detect and inhibit virus entry inside the host cell. This inhibition and detection properties of nanoparticles can be of interest for developing vaccines and treatments of COVID-19. It was observed that basic reproduction number, case fatality rate and incubation period are the most common factors in the epidemiology of several viral diseases that can be prevented by taking supportive treatment and preventive strategies without specific therapeutic intervention. However, it is now obvious that early detection is one of the best ways to break the spread of the virus until an effective and safe vaccine/medication or therapy is developed.

Currently, novel technologies and improvements in nanoscience can be used to detect and treat respiratory diseases caused by viruses. This review can be helpful and give insight into the upcoming studies for the development of nanomedicine against SARS-CoV-2 [160]. Moreover, the limitations caused by conventional and subunit vaccines can be solved by applying nanoparticles therapeutic approaches due to their unique nature, such as size, shape, surface area, and ability to functionalize, which causes strong immunogenicity and enhanced antigen presentation. The polymeric nanoparticle of Poly (lactic-co-glycolic acid) can be used in the human body without any side effect approved by the Food and Drug Administration [161]. As per the antibacterial and antifungal studies, inorganic nanoparticles based mainly on gold, silver, and zinc are among the best candidates for biomedical applications [106-110, 129-131, 162]. As per the data, the required conformational specific antibodies which are active to nullify the SARS-CoV infections via NPsbased systems were synthesized by the researchers [163]. Nowadays the researchers are actively monitoring peptidebased nanoparticles. The peptide inhibitor extracted from the protein ACE2 gives an extra edge for blocking SARSCoV-2, whose binding efficiency can be increased with multiple binding of nanocarrier linked peptides [164]. But the toxicity of NPs should be carefully taken care of while designing the theragnostic NPs for respiratory diseases.
Novel NPs reported reference to exhibit the following properties: easy penetration through the mucus membrane without sticking, biodegradable and less toxic, causing no lesions during treatment, easily modifiable chemical structure while adding surface capping agents.

From the previous studies for other types of viruses, nano-based vaccines have proven as a compelling candidate. Therefore, one of the future studies should be on the practical usage of polymeric nanoparticles as a drug/vaccine to develop long term immunization against coronaviruses. These nanomaterials may help in improving the sensitivity, detection limit, and analysis time of coronaviruses. Also, the potentiality of the electrochemical devices and techniques such as colorimetric sensing, electrochemiluminescence, immunosensing, electrochemical sensor, photoluminescence and chiroimmunosensing to find out the coronaviruses must be studied thoroughly.

Author Contributions YU contributed with the abstract, introduction, polymeric materials, mechanism of viruses, detection, diagnosis, conclusion, and future recommendations. PAS involved with the abstract, introduction, polymeric materials, conclusion, and future recommendations. HR contributed the abstract, introduction, polymeric materials, and conclusion. OA participated with the abstract, introduction, mechanism of the virus, detection, diagnosis, illustrations, future recommendations and references. AS and ZS helped with the introduction, polymeric materials, mechanism of virus and detection. SAB contributed with the introduction, polymeric materials, conclusion and future recommendations, and SKMH formulated the study and contributed with the abstract, introduction, polymeric materials, mechanism of viruses, detection, diagnosis, conclusion, future recommendation, and references. All the authors extensively reviewed the paper, provide areas of improvement, and added substantive information.

\section{References}

1. Afrough B, Dowall S, Hewson R (2019) Emerging viruses and current strategies for vaccine intervention. Clin Exp Immunol 196:157-166. https://doi.org/10.1111/cei.13295

2. Cui J, Li F, Shi ZL (2019) Origin and evolution of pathogenic coronaviruses. Nat Rev Microbiol 17:181-192. https://doi.org/ 10.1038/s41579-018-0118-9

3. Sahin AR (2020) 2019 Novel coronavirus (COVID-19) outbreak: a review of the current literature. Eur J Med Oncol https://doi. org/10.14744/ejmo.2020.12220.

4. Bleibtreu A, Bertine M, Bertin C, Houhou-Fidouh N, Visseaux B (2019) Focus on middle east respiratory syndrome coronavirus (MERS-CoV). Med Mal Infect. https://doi.org/10.1016/j.medmal.2019.10.004

5. Ghani AC, Donnelly CA, Cox DR, Griffin JT, Fraser C, Lam TH, Ho LM, Chan WS, Anderson RM, Hedley AJ, Leung GM (2005) Methods for estimating the case fatality ratio for a novel, emerging infectious disease. Am J Epidemiol 162:479-486. https://doi. org/10.1093/aje/kwi230

6. Wallinga J, Teunis P (2004), ORIGINAL CONTRIBUTIONS different epidemic curves for severe acute respiratory syndrome reveal similar impacts of control measures. https://academic.oup. com/aje/article-abstract/160/6/509/79472. 
7. SARS Frequently asked questions, (n.d.). https://www.cdc.gov/ sars/about/faq.pdf. Accessed 11 July 2021

8. Consensus document on the epidemiology of severe acute respiratory syndrome (SARS), (n.d.). https://www.who.int/csr/sars/ en/WHOconsensus.pdf. Accessed 11 July 2021

9. Kucharski AJ, Althaus CL, The role of superspreading in Middle East respiratory syndrome coronavirus (MERS-CoV) transmission, n.d. http://www.eurosurveillance.org/ViewArticle.aspx? ArticleId $=21167$.

10. MERS clinical features, (n.d.). https://www.cdc.gov/coronavirus/ mers/clinical-features.html. Accessed 11 July 2021

11. Alsolamy S, Arabi Y (2015) Infection with Middle East respiratory syndrome coronavirus. Can J Respir Ther 51:102-103

12. Li Q, Guan X, Wu P, Wang X, Zhou L, Tong Y, Ren R, Leung KSM, Lau EHY, Wong JY, Xing X, Xiang N, Wu Y, Li C, Chen Q, Li D, Liu T, Zhao J, Liu M, Tu W, Chen C, Jin L, Yang R, Wang Q, Zhou S, Wang R, Liu H, Luo Y, Liu Y, Shao G, Li H, Tao Z, Yang Y, Deng Z, Liu B, Ma Z, Zhang Y, Shi G, Lam TTY, Wu JT, Gao GF, Cowling BJ, Yang B, Leung GM, Feng Z (2020) Early transmission dynamics in Wuhan, China, of novel coronavirus-infected pneumonia. N Engl J Med 382:1199-1207. https://doi.org/10.1056/NEJMoa2001316

13. Riou J, Althaus CL (2020) Pattern of early human-to-human transmission of Wuhan 2019 novel coronavirus (2019-nCoV), December 2019 to January 2020, Eurosurveillance. 25. https:// doi.org/10.2807/1560-7917.ES.2020.25.4.2000058.

14. Wu JT, Leung K, Bushman M, Kishore N, Niehus R, de Salazar PM, Cowling BJ, Lipsitch M, Leung GM (2020) Estimating clinical severity of COVID-19 from the transmission dynamics in Wuhan, China. Nat Med 26:506-510. https://doi.org/10.1038/ s41591-020-0822-7

15. Sanche S, Lin YT, Xu C, Romero-Severson E, Hengartner N, $\mathrm{Ke} \mathrm{R}$, The novel coronavirus, 2019-nCoV, is highly contagious and more infectious than initially estimated, (n.d.). https://doi. org/10.1101/2020.02.07.20021154.

16. Linton NM, Kobayashi T, Yang Y, Hayashi K, Akhmetzhanov AR, Jung S, Yuan B, Kinoshita R, Nishiura H (2020) Incubation period and other epidemiological characteristics of 2019 novel coronavirus infections with right truncation: a statistical analysis of publicly available case data. J Clin Med 9:538. https://doi.org/ 10.3390/jcm9020538

17. Cheng-Jun Y, Zi-Xiao W, Yue X, Ming-Xia H, Kai C, Gang Q (2021) Assessment of basic reproductive number for COVID-19 at global level. Medicine 100:e25837. https://doi.org/10.1097/ MD.0000000000025837

18. Khan A, Naveed M, Dur-e-Ahmad M, Imran M (2015) Estimating the basic reproductive ratio for the Ebola outbreak in Liberia and Sierra Leone. Infect Dis Poverty. https://doi.org/10.1186/ s40249-015-0043-3

19. Are the Ebola outbreaks in Nigeria and Senegal over?, (n.d.). https://www.who.int/mediacentre/news/ebola/14-october-2014. Accessed 18 May 2020

20. Ebola virus disease, (n.d.). https://www.who.int/en/news-room/ fact-sheets/detail/ebola-virus-disease. Accessed 17 May 2020

21. Fauquet C, Mayo MA, Maniloff J, Desselberger U, Ball LA (2005) Virus taxonomy 1st edition VIIIth report of the international committee on taxonomy of viruses, 8th ed

22. Health care worker information (2020) https://www.hse.ie/eng/ health/immunisation/hcpinfo/guidelines/chapter23.pdf. Accessed 17 May 2020

23. Chickenpox for healthcare professionals, (n.d.). https://www.cdc. gov/chickenpox/hcp/index.html. Accessed 18 May 2020

24. Wormser GP, Colebunders RL (2009) Issue Cover Volume 49Issue 815 October 2009 Comments $(0)<$ Previous Next $>$ Control of Communicable Diseases Manual, 19th Edition Edited by David L. Heymann Washington, DC: American
Public Health Association. Clin Infect Dis 49: 1292-1293. https://doi.org/10.1086/605668.

25. Gani R, Leach S (2001) Transmission potential of smallpox in contemporary populations. Nature 414:748-751. https://doi. org/10.1038/414748a

26. Frequently asked questions and answers on smallpox, (n.d.). https://www.who.int/csr/disease/smallpox/faq. Accessed 17 May 2020

27. Coburn BJ, Wagner BG, Blower S (2009) Modeling influenza epidemics and pandemics: Insights into the future of swine flu (H1N1). BMC Med 7:1-8. https://doi.org/10.1186/ 1741-7015-7-30

28. Influenza (Flu), (n.d.). https://www.cdc.gov/flu. Accessed 17 May 2020

29. Guerra FM, Bolotin S, Lim G, Heffernan J, Deeks SL, Li Y, Crowcroft NS (2017) The basic reproduction number (R0) of measles: a systematic review. Lancet Infect Dis 17:e420-e428. https://doi.org/10.1016/S1473-3099(17)30307-9

30. Measles virus, (n.d.). https://www.cdc.gov/vaccines/pubs/ pinkbook/downloads/meas.pdf. Accessed 17 May 2020

31. Daniel NPS, Shumer E, Nokoff NJ (2017) An assessment of the impact of heterogeneity in vaccine uptake due to religious and philosophical exemptions on the potential for outbreaks. Physiol Behav 176:139-148. https://doi.org/10.1016/j.physb eh.2017.03.040

32. Mumps for health care providers, (n.d.). https://www.cdc.gov/ mumps/hcp.html. Accessed 17 May 2020

33. Ng SC, Tilg H (2020) COVID-19 and the gastrointestinal tract: more than meets the eye. Gut. https://doi.org/10.1136/ gutjnl-2020-321195

34. Yan CH, Faraji F, Prajapati Bs DP, Boone CE, Deconde AS, Association of chemosensory dysfunction and covid-19 in patients presenting with influenza-like symptoms, (n.d.). https://doi.org/10.1111/alr.22579.

35. Pal M, Berhanu G, Desalegn C, Kandi V (2020) Severe acute respiratory syndrome coronavirus-2 (SARS-CoV-2): an update. Cureus. https://doi.org/10.7759/cureus.7423

36. Centers for disease control and prevention, interim clinical guidance for management of patients with confirmed coronavirus disease (COVID-19), (n.d.). https://www.cdc.gov/coron avirus/2019-ncov/hcp/clinical-guidance-management-patients. html. Accessed 17 May 2020

37. Wu X, Cai Y, Huang X, Yu X, Zhao L, Wang F, Li Q, Gu S, Xu T, Li Y, Lu B, Zhan Q (2020) Co-infection with SARSCoV-2 and influenza A virus in patient with pneumonia, China. Emerg Infect Dis 26:1324-1326. https://doi.org/10.3201/eid26 06.200299

38. Coronavirus disease (COVID-19) technical guidance: Patient management, (n.d.). https://www.who.int/emergencies/disea ses/novel-coronavirus-2019/technical-guidance/patient-manag ement. Accessed 17 May 2020

39. Zhang J, Litvinova M, Liang Y, Wang Y, Wang W, Zhao S, Wu Q, Merler S, Viboud C, Vespignani A, Ajelli M, Yu H (2020) Age profile of susceptibility, mixing, and social distancing shape the dynamics of the novel coronavirus disease 2019 outbreak in China. MedRxiv. https://doi.org/10.1101/2020.03. 19.20039107

40. Chinese Center for disease control and prevention Epidemiology working group for NCIP epidemic response (2020) The epidemiological characteristics of an outbreak of 2019 novel coronavirus diseases (COVID-19) in China. Zhonghua Liu Xing Bing Xue Za Zhi 41: 145-151. https://doi.org/10.3760/cma.j.issn.0254-6450. 2020.02.003.

41. Bianculli RH, Mase JD, Schulz MD (2020) Antiviral polymers: past approaches and future possibilities. Macromolecules 53(21):9158-9186 
42. Armentano I, Barbanera M, Carota E, Crognale S, Marconi M, Rossi S, Rubino G, Scungio M, Taborri J, Calabrò G (2021) Polymer materials for respiratory protection: processing, end use, and testing methods. ACS Appl Polym Mater 3(2):531-548

43. Tandon R, Sharp JS, Zhang F, Pomin VH, Ashpole NM, Mitra D, Jin W, Liu H, Sharma P, Linhardt RJ (2021) Effective inhibition of SARS-CoV-2 entry by heparin and enoxaparin derivatives. J Virol 95(3):e01987-e2020. https://doi.org/10.1128/JVI.01987-20

44. Tang Z, Kong N, Zhang X, Liu Y, Hu P, Mou S, Liljestrom P, Shi J, Tan W, Kim JS, Cao Y, Langer R, Leong KW, Farokhzad OC, Tao W (2020) A materials-science perspective on tackling COVID-19. Nat Rev Mater 5:847-860. https://doi.org/10.1038/ s41578-020-00247-y

45. Randazzo W, Fabra MJ, Falco I, Lopez-Rubio A, Shanchez G (2018) Polymers and biopolymers with antiviral activity: potential applications for improving food safety. Compr Rev Food Sci Food Safety 17:754-768

46. Pemmada R, Zhu X, Dash M, Zhou Y, Ramakrishna S, Peng X, Thomas V, Jain S, Nanda HS (2020) Science-based strategies of antiviral coatings with viricidal properties for the COVID-19 like pandemics. Mater 13(18):4041. https://doi.org/10.3390/ma131 84041

47. Panday LM (2020) Surface engineering of personal protective equipments (PPEs) to prevent the contagious infections of SARSCoV-2. Surface Engg 36:901-907

48. Malik NS, Ahmad M, Minhas MU, Tulain R, Barkat K, Khalid I, Khalid Q (2020) Chitosan/Xanthan gum based hydrogels as potential carrier for an antiviral drug: fabrication, characterization, and safety evaluation. Front Chem. https://doi.org/10.3389/ fchem.2020.00050

49. Don TM, Chen HR (2005) Synthesis and characterization of ABcrosslinked graft copolymers based on maleilated chitosan and N-isopropylacrylamide. Carbohydr Polym 61:334-347. https:// doi.org/10.1016/j.carbpol.2005.05.025

50. Cheba BA (2011), Chitin and chitosan: marine biopolymers with unique properties and versatile applications

51. Synowiecki J, Al-khateeb NA, Synowiecki J (2010) Production, properties, and some new applications of chitin and its derivatives. Crit Rev Food Sci Nutr 43(3):145-171

52. Kim S (2018) Competitive biological activities of chitosan and its derivatives: antimicrobial, antioxidant, anticancer, and antiinflammatory activities. Int J Polym Sci. https://doi.org/10.1155/ 2018/1708172

53. Cheung RCF, Ng TB, Wong JH, Chan WY (2015) Chitosan: an update on potential biomedical and pharmaceutical applications. Mar Drugs 13:5156-5186. https://doi.org/10.3390/md13085156

54. Aranaz I, Mengibar M, Harris R, Panos I, Miralles B, Acosta N, Galed G, Heras A (2009) Functional characterization of chitin and chitosan. Curr Chem Biol 3:203-230. https://doi.org/10. 2174/187231309788166415

55. Darder M, Colilla M, Ruiz-Hitzky E (2003) Biopolymer-clay nanocomposites based on chitosan intercalated in montmorillonite. Chem Mater 15:3774-3780. https://doi.org/10.1021/cm034 3047

56. Kim SE, Cho YW, Kang EJ, Kwon IC, Lee EB, Kim JH, Chung H, Jeong SY (2001) Three-dimensional porous collagen/chitosan complex sponge for tissue engineering

57. Qin Y (2008) The preparation and characterization of chitosan wound dressings with different degrees of acetylation. J Appl Polym Sci 107:993-999. https://doi.org/10.1002/app.27183

58. Milewska A, Ciejka J, Kaminski K, Karewicz A, Bielska D, Zeglen S, Karolak W, Nowakowska M, Potempa J, Bosch BJ, Pyrc K, Szczubialka K (2013) Novel polymeric inhibitors of HCoV-NL63. Antiviral Res 97:112-121. https://doi.org/10. 1016/j.antiviral.2012.11.006
59. Lee EJ, Kim YH (2010) Synthesis and thermo-responsive properties of chitosan-g-poly (N-isopropylacrylamide) and HTCCg-poly(N-isopropylacrylamide) copolymers. Fibers Polym 11:164-169. https://doi.org/10.1007/s12221-010-0164-z

60. Kim Y, Nam C, Choi JW, Jang J (2003) Durable antimicrobial treatment of cotton fabrics using chloride and polycarboxylic acids. J Appl Polym Sci 88:1567-1572

61. Kamiński K, Szczubiałka K, Zazakowny K, Lach R, Nowakowska M (2010) Chitosan derivatives as novel potential heparin reversal agents. J Med Chem 53:4141-4147. https://doi.org/10. 1021/jm1001666

62. Krzysztof PYRCAleksandra MILEWSKAMaria NowakowskaKrzysztof SzczubialkaKamil Kaminski (2013) The use of chitosan polymer in the treatment and prevention of infections caused by coronaviruses. https://doi.org/10.1016/0014-3057(91)90111-Z

63. Zhang C, Cheng Y, Qu G, Wu X, Ding Y, Cheng Z, Yu L, Ping $Q$ (2008) Preparation and characterization of galactosylated chitosan coated BSA microspheres containing 5-fluorouracil. Carbohydr Polym 72:390-397. https://doi.org/10.1016/j.carbpol.2007. 09.004

64. Jones ST, Cagno V, Janeček M, Ortiz D, Gasilova N, Piret J, Gasbarri M, Constant DA, Han Y, Vuković L, Král P, Kaiser L, Huang S, Constant S, Kirkegaard K, Boivin G, Stellacci F, Tapparel C (2020) Modified cyclodextrins as broad-spectrum antivirals. http://advances.sciencemag.org/.

65. Wang W et al (2011) In vitro inhibitory effect of carrageenan oligosaccharide on influenza A H1N1 virus. Antiviral Res 92:237-246. https://doi.org/10.1016/j.antiviral.2011.08.010

66. Gonzalez ME, Alarcon B, Carrasco L (1987) Polysaccharides as antiviral agents: antiviral activity of carrageenan. Antimicrob Agents Chemother 31:1388-1393. https://doi.org/10.1128/aac. 31.9.1388

67. Talarico LB et al (2005) Te antiviral activity of sulfated polysaccharides against dengue virus is dependent on virus serotype and host cell. Antiviral Res 66:103-110. https://doi.org/10.1016/j. antiviral.2005.02.001

68. Talarico LB, Noseda MD, Ducatti DRB, Duarte MER, Damonte EB (2011) Differential inhibition of dengue virus infection in mammalian and mosquito cells by iota-carrageenan. J Gen Virol 92:1332-1342. https://doi.org/10.1099/vir.0.028522-0

69. Chiu YH, Chan YL, Tsai LW, Li TL, Wu CJ (2012) Prevention of human enterovirus 71 infection by kappa carrageenan. Antiviral Res 95:128-134. https://doi.org/10.1016/j.antiviral.2012.05.009

70. Grassauer A et al (2008) Iota-Carrageenan is a potent inhibitor of rhinovirus infection. Virol J 5:107. https://doi.org/10.1186/ 1743-422X-5-107

71. Pandey AP, Sawant KK (2016) Polyethylenimine: A versatile, multifunctional non-viral vector for nucleic acid delivery. Mater Sci Eng C 68:904-918. https://doi.org/10.1016/j.msec.2016.07. 066

72. Zintchenko A, Philipp A, Dehshahri A, Wagner E (2008) Simple modifications of branched PEI lead to highly efficient siRNA carriers with low toxicity. Bioconjug Chem 19:1448-1455. https:// doi.org/10.1021/bc800065f

73. Rackstraw BJ, Martin AL, Stolnik S, Roberts CJ, Garnett MC, Davies MC, Tendler SJB (2001) Microscopic investigations into PEG-cationic polymer-induced DNA condensation. Langmuir 17:3185-3193. https://doi.org/10.1021/la001456x

74. Lin W, Coombes AGA, Davies MC, Davis SS, Illum L (1993) Preparation of sub-100 nm human serum albumin nanospheres using a ph-coacervation method. J Drug Target 1:237-243. https://doi.org/10.3109/10611869308996081

75. Tiyaboonchai W, Woiszwillo J, Middaugh CR (2001) Formulation and characterization of amphotericin B-polyethyleniminedextran sulfate nanoparticles. J Pharm Sci 90:902-914. https:// doi.org/10.1002/jps. 1042 
76. Forrest ML, Meister GE, Koerber JT, Pack DW (2004) Partial acetylation of polyethylenimine enhances in vitro gene delivery

77. Astete CE, Kumar CSSR, Sabliov CM (2007) Size control of poly(d, 1-lactide-co-glycolide) and poly(d, l-lactide-coglycolide)-magnetite nanoparticles synthesized by emulsion evaporation technique. Colloids Surf A Physicochem Eng Asp 299:209-216. https://doi.org/10.1016/j.colsurfa.2006.11.055

78. Mazumder A, Davis J, Rangari V, Curry M (2013) Synthesis characterization, and applications of dendrimer-encapsulated zero-valent $\mathrm{Ni}$ nanoparticles as antimicrobial agents. ISRN Nanomater 2013:1-9. https://doi.org/10.1155/2013/843709

79. Scott RWJ, Wilson OM, Crooks RM (2005) Synthesis, characterization, and applications of dendrimer-encapsulated nanoparticles. J Phys Chem B 109:692-704. https://doi.org/10.1021/jp046 9665

80. Abbasi E, Aval SF, Akbarzadeh A, Milani M, Nasrabadi HT, Joo SW, Hanifehpour Y, Nejati-Koshki K, Pashaei-Asl R (2014) Dendrimers: synthesis, applications, and properties. Nanoscale Res Lett 9:1-10. https://doi.org/10.1186/1556-276X-9-247

81. El Brahmi N, El Kazzouli S, Mignani SM, Essassi EM, Aubert G, Laurent R, Caminade AM, Bousmina MM, Cresteil T, Majoral JP (2013) Original multivalent copper(II)-conjugated phosphorus dendrimers and corresponding mononuclear copper(II) complexes with antitumoral activities. Mol Pharm 10:1459-1464. https://doi.org/10.1021/mp4000184

82. Mignani S, Majoral JP (2013) Dendrimers as macromolecular tools to tackle from colon to brain tumor types: a concise overview. New J Chem 37:3337-3357. https://doi.org/10.1039/c3nj0 0300k

83. Mignani S, Rodrigues J, Roy R, Shi X, Ceña V, El Kazzouli S, Majoral JP (2019) Exploration of biomedical dendrimer space based on in-vitro physicochemical parameters: key factor analysis (Part 1). Drug Discov Today 24:1176-1183. https://doi.org/ 10.1016/j.drudis.2019.02.014

84. Mignani S, Rodrigues J, Roy R, Shi X, Ceña V, El Kazzouli S, Majoral JP (2019) Exploration of biomedical dendrimer space based on in-vivo physicochemical parameters: Key factor analysis (Part 2). Drug Discov Today 24:1184-1192. https://doi.org/ 10.1016/j.drudis.2019.03.001

85. Zhang Y, Liu X, Li L, Guo Z, Xue Z, Lu X (2016) An electrochemical paracetamol sensor based on layer-by-layer covalent attachment of MWCNTs and a G4.0 PAMAM modified GCE. Anal Methods 8:2218-2225. https://doi.org/10.1039/c5ay03241e

86. Ochekpe NA, Olorunfemi PO, Ngwuluka NC (2009) Nanotechnology and drug delivery part 2: nanostructures for drug delivery. http://www.tjpr.org.

87. Kumar A, Ma H, Zhang X, Huang K, Jin S, Liu J, Wei T, Cao W, Zou G, Liang XJ (2012) Gold nanoparticles functionalized with therapeutic and targeted peptides for cancer treatment. Biomaterials 33:1180-1189. https://doi.org/10.1016/j.biomaterials.2011. 10.058

88. McNeil SE (2009) Unique benefits of nanotechnology to drug delivery and diagnostics. Natl Inst Stand Technol 21702:71-82. https://doi.org/10.1007/978-1-60327-198-1

89. Caron J, Reddy LH, Lepêtre-Mouelhi S, Wack S, Clayette P, Rogez-Kreuz C, Yousfi R, Couvreur P, Desmaële D (2010) Squalenoyl nucleoside monophosphate nanoassemblies: new prodrug strategy for the delivery of nucleotide analogues. Bioorgan Med Chem Lett 20:2761-2764. https://doi.org/10.1016/j. bmcl.2010.03.070

90. Gagliardi M (2017) Biomimetic and bioinspired nanoparticles for targeted drug delivery. Ther Deliv 8:289-299. https://doi.org/10. 4155/tde-2017-0013

91. Sanvicens N, Marco MP (2008) Multifunctional nanoparticles properties and prospects for their use in human medicine. Trends
Biotechnol 26:425-433. https://doi.org/10.1016/j.tibtech.2008. 04.005

92. Chiappetta DA, Facorro G, Rubin de Celis E, Sosnik A (2011) Synergistic encapsulation of the anti-HIV agent efavirenz within mixed poloxamine/poloxamer polymeric micelles, Nanomedicine Nanotechnology. Biol Med 7:624-637. https://doi.org/10.1016/j nano.2011.01.017

93. Nivedh K, Namasivayam SKR, Nishanth AN (2016) Effect of functionalization of polymeric nanoparticles incorporated with whole attenuated rabies virus antigen on sustained release and efficacy. Resour Technol 2:S25-S38. https://doi.org/10.1016/j. reffit.2016.10.007

94. Das Neves J, Araújo F, Andrade F, Michiels J, Ariën KK, Vanham G, Amiji M, Bahia MF, Sarmento B (2013) In vitro and Ex Vivo evaluation of polymeric nanoparticles for vaginal and rectal delivery of the anti-HIV drug dapivirine. Mol Pharm 10:2793-2807

95. Zhou J, Zexu Hu, Zabihi F, Chen Z, Zhu M (2020) Progress and perspective of antiviral protective material. Adv Fiber Mater 2:123-139. https://doi.org/10.1007/s42765-020-00047-7

96. Jiang X, Li Z, Young DJ et al (2021) Toward the prevention of coronavirus infection: what role can polymers play? Mater Today Adv 10:100140

97. Rahman H (2021) Transmission, prevention and therapeutic strategies for COVID-19: updates and challenges. Coronaviruses. https://doi.org/10.2174/2666796702666210308114216

98. Bernkop-Schnürch A, Dünnhaupt S (2012) Chitosan-based drug delivery systems. Eur J Pharm Biopharm 81:463-469. https://doi. org/10.1016/j.ejpb.2012.04.007

99. Milewska A, Chi Y, Szczepanski A, Barreto-Duran E, Liu K, Liu D, Guo X, Ge Y, Li J, Cui L, Ochman M, Urlik M, RodziewiczMotowidlo S, Zhu F, Szczubialka K, Pyrc K, HTCC as a highly effective polymeric inhibitor of SARS-CoV-2 and MERS-CoV 2 3, (n.d.). httpps://doi.org/https://doi.org/10.1101/2020.03.29. 014183.

100. Liu W, Zhu Y, Wang F, Li X, Liu X, Pang J, Pan W (2018) Galactosylated chitosanfunctionalized mesoporous silica nanoparticles for efficient colon cancer cell-targeted drug delivery. R Soc Open Sci 5:181027. https://doi.org/10.1098/rsos.181027

101. Braga SS (2019) Cyclodextrins: emerging medicines of the new millennium. Biomolecules 9:801. https://doi.org/10.3390/biom9 120801

102. Jang Y, Shin H, Lee MK et al (2021) Antiviral activity of lambda-carrageenan against influenza viruses and severe acute respiratory syndrome coronavirus 2 . Sci Rep 11:821. https://doi. org/10.1038/s41598-020-80896-9

103. Shen C, Li J, Zhang Y, Li Y, Shen G, Zhu J, Tao J, Hospital U (2017) Polyethylenimine-based micro/nanoparticles as vaccine adjuvants. Int J Nanomedicine 12:5443-5460

104. Ansary RH, Awang MB, Rahman MM (2014) Biodegradable poly(D, L-lactic-co-glycolic acid)-based micro/nanoparticles for sustained release of protein drugs - A review. Trop J Pharm Res 13:1179-1190. https://doi.org/10.4314/tjpr.v13i7.24

105. Dzmitruk V, Shcharbin D, Pedziwiatr-Werbicka E, Bryszewska M (2011) Dendrimers in anti-HIV therapy. Adv Nanocomp Technol Intech Open. https://doi.org/10.1016/j.colsurfa.2011.12.014

106. Lara HH, Ayala-Nuñez NV, Ixtepan-Turrent L, Rodriguez-Padilla C (2010) Mode of antiviral action of silver nanoparticles against HIV-1. J Nanobiotechnol. https://doi.org/10.1186/1477-3155-8-1

107. Hu RL, Li SR, Kong FJ, Hou RJ, Guan XL, Guo F (2014) Inhibition effect of silver nanoparticles on herpes simplex virus 2 . Genet Mol Res 13:7022-7028. https://doi.org/10.4238/2014. March.19.2

108. Khandelwal N, Kaur G, Chaubey KK, Singh P, Sharma S, Tiwari A, Singh SV, Kumar N (2014) Silver nanoparticles 
impair Peste des petits ruminants virus replication. Virus Res 190:1-7. https://doi.org/10.1016/j.virusres.2014.06.011

109. Huy TQ, Hien Thanh NT, Thuy NT, Van Chung P, Hung PN, Le A-T, Hong Hanh NT (2017) Cytotoxicity and antiviral activity of electrochemical - synthesized silver nanoparticles against poliovirus. J Virol Methods 241:52-57. https://doi.org/ 10.1016/j.jviromet.2016.12.015

110. Castro-Mayorga JL, Randazzo W, Fabra MJ, Lagaron JM, Aznar R, Sánchez G (2017) Antiviral properties of silver nanoparticles against norovirus surrogates and their efficacy in coated polyhydroxyalkanoates systems. LWT - Food Sci Technol 79:503-510. https://doi.org/10.1016/j.lwt.2017.01.065

111. Nabil A, Salem B, Zyed R, Lassoued MA, Nidhal S, Sfar S, Mahjoub A (2012) Plant-derived nanoparticles enhance antiviral activity against coxsakievirus b3 by acting on virus particles and vero cells. Digest J Nanomat Biostruc 7:737-744

112. Gaikwad S, Ingle A, Gade A, Rai M, Falanga A, Incoronato N, Russo L, Galdiero S, Galdiero M (2013) Antiviral activity of mycosynthesized silver nanoparticles against herpes simplex virus and human parainfluenza virus type 3 . Int J Nanomed 8:4303-4314. https://doi.org/10.2147/IJN.S50070

113. Fatima M, Zaidi USS, Amraiz D, Afzal F (2015) In vitro antiviral activity of Cinnamomum cassia and its nanoparticles against H7N3 influenza a virus. J Microbiol Biotechnol 26:151-159. https://doi.org/10.4014/jmb.1508.08024

114. Rónavári A, Kovács D, Igaz N, Vágvölgyi C, Boros IM, Kónya Z, Pfeiffer I, Kiricsi M (2017) Biological activity of greensynthesized silver nanoparticles depends on the applied natural extracts: a comprehensive study. Int J Nanomed 12:871-883. https://doi.org/10.2147/IJN.S122842

115. Seino S, Imoto Y, Kosaka T, Nishida T, Nakagawa T, Yamamoto TA (2016) Antiviral activity of silver nanoparticles immobilized onto textile fabrics synthesized by radiochemical process. MRS Adv Mater Res Soc. https://doi.org/10.1557/adv. 2016.43

116. Levina AS, Repkova MN, Zarytova VF, Mazurkova NA (2015) TiO2 DNA nanocomposites as efficient site-specific antiviral agents against influenza A virus in cell culture, in: IEEE-NANO 2015 - 15th Int. Conf. Nanotechnol., Institute of Electrical and Electronics Engineers Inc 1509-1512. https://doi.org/10.1109/ NANO.2015.7388929.

117. Syngouna VI, Chrysikopoulos CV (2017) Inactivation of MS2 bacteriophage by titanium dioxide nanoparticles in the presence of quartz sand with and without ambient light. J Colloid Interface Sci 497:117-125. https://doi.org/10.1016/j.jcis.2017.02.059

118. Chunduri LAA, Kurdekar A, Haleyurgirisetty MK, Bulagonda EP, Kamisetti V, Hewlett IK (2017) Femtogram level sensitivity achieved by surface engineered silica nanoparticles in the early detection of HIV infection. Sci Rep. https://doi.org/10.1038/ s41598-017-07299-1

119. Yang XX, Li CM, Li YF, Wang J, Huang CZ (2017) Synergistic antiviral effect of curcumin functionalized graphene oxide against respiratory syncytial virus infection. Nanoscale 9:1608616092. https://doi.org/10.1039/c7nr06520e

120. Dong X, Moyer MM, Yang F, Sun YP, Yang L (2017) Carbon dots' antiviral functions against noroviruses. Sci Rep. https://doi. org/10.1038/s41598-017-00675-x

121. Deng L, Mohan T, Chang TZ, Gonzalez GX, Wang Y, Kwon YM, Kang SM, Compans RW, Champion JA, Wang BZ (2018) Double-layered protein nanoparticles induce broad protection against divergent influenza A viruses. Nat Commun. https://doi. org/10.1038/s41467-017-02725-4

122. Deng L, Chang TZ, Wang Y, Li S, Wang S, Matsuyama S, Yu G, Compans RW, Li JD, Prausnitz MR, Champion JA, Wang BZ (2018) Heterosubtypic influenza protection elicited by doublelayered polypeptide nanoparticles in mice. Proc Natl Acad Sci
USA 115:E7758-E7767. https://doi.org/10.1073/pnas.18057 13115

123. Wang X, Akagi T, Akashi M, Baba M (2007) Development of core-corona type polymeric nanoparticles as an anti-HIV-1 vaccine. Mini Rev Org Chem 4:51-59. https://doi.org/10.2174/ 157019307779815857

124. Joshy KS, Snigdha S, Anne G, Nandakumar K, Laly P, Sabu AT (2018) Poly (vinyl pyrrolidone)-lipid based hybrid nanoparticles for anti viral drug delivery. Chem Phys Lipids 210:82-89. https:// doi.org/10.1016/j.chemphyslip.2017.11.003

125. Chen HW, Fang ZS, Chen YT, Chen YI, Yao BY, Cheng JY, Chien CY, Chang YC, Hu CMJ (2017) Targeting and enrichment of viral pathogen by cell membrane cloaked magnetic nanoparticles for enhanced detection. ACS Appl Mater Interfaces 9:39953-39961. https://doi.org/10.1021/acsami.7b09931

126. Gao Y, Han K, Wang Q, Hu Z, Liu Q, Liu L, Zeng K (2018) Development of podophyllotoxin-loaded nanostructured lipid carriers for the treatment of condyloma acuminatum. Mol Med Rep 17:6506-6514. https://doi.org/10.3892/mmr.2018.8696

127. Chahal JS, Fang T, Woodham AW, Khan OF, Ling J, Anderson DG, Ploegh HL (2017) An RNA nanoparticle Vaccine against Zika virus elicits antibody and CD8+ T cell responses in a mouse model. SciRep. https://doi.org/10.1038/s41598-017-00193-w

128. Asgary V, Shoari A, Afshar Moayad M, Shafiee Ardestani M, Bigdeli R, Ghazizadeh L, Khosravy MS, Panahnejad E, Janani A, Bashar R, Abedi M, Ahangari Cohan R (2018) Evaluation of G2 citric acid-based dendrimer as an adjuvant in veterinary rabies vaccine. Viral Immunol. 31:47-54. https://doi.org/10.1089/vim. 2017.0024

129. Wang C, Zhu W, Luo Y, Wang BZ (2018) Gold nanoparticles conjugating recombinant influenza hemagglutinin trimers and flagellin enhanced mucosal cellular immunity, Nanomedicine Nanotechnology. Biol Med 14:1349-1360. https://doi.org/10. 1016/j.nano.2018.03.007

130. Tao W, Hurst BL, Shakya AK, Uddin MJ, Ingrole RSJ, Hernandez-Sanabria M, Arya RP, Bimler L, Paust S, Tarbet EB, Gill HS (2017) Consensus M2e peptide conjugated to gold nanoparticles confers protection against $\mathrm{H} 1 \mathrm{~N} 1, \mathrm{H} 3 \mathrm{~N} 2$ and $\mathrm{H} 5 \mathrm{~N} 1$ influenza A viruses. Antiviral Res 141:62-72. https://doi.org/10.1016/j.antiv iral.2017.01.021

131. Liu Y, Zhang L, Wei W, Zhao H, Zhou Z, Zhang Y, Liu S (2015) Colorimetric detection of influenza A virus using antibody-functionalized gold nanoparticles. Analyst 140:3989-3995. https:// doi.org/10.1039/c5an00407a

132. Li J, Fei Yu, Chen Yi (2015) David Oupick'y, Polymeric drugs: advances in the development of pharmacologically active polymers. J Control Release. https://doi.org/10.1016/j.jconrel.2015. 09.043

133. Milewska A, Kaminski K, Ciejka J, Kosowicz K, Zeglen S, Wojarski J, Nowakowska M, Szczubiałka K, Pyrc K (2016) HTCC: Broad Range Inhibitor of Coronavirus Entry. PLoS One 11:e0156552. https://doi.org/10.1371/journal.pone.0156552

134. Kamil K, Aleksandra M, Maria N, Krzysztof P, Krzysztof S (2015) The use of Chitosan polymer in the treatment and prevention of infections caused by coronaviruses. USA Patent US20150164938A1

135. Milewska A et al (2021) Journal of Virology, HTCC as a Polymeric Inhibitor of SARS-CoV-2 and MERS-CoV 95(4):e0162220. https://doi.org/10.1128/JVI.01622-20.

136. Garrido PF, Calvelo M, Blanco-González A, Veleiro U, Suárez F, Conde D, Cabezón A, Piñeiro Á, Garcia-Fandino R (2020) the lord of the nanorings: cyclodextrins and the battle against SARSCoV-2. Int J Pharm 588:119689. https://doi.org/10.1016/j.ijpha rm.2020.119689

137. Sun P, Lu X, Xu C, Wang Y, Sun W, Xi J (2020) CD-sACE2 inclusion compounds: an effective treatment for coronavirus 
disease 2019 (COVID-19). J Med Virol JMV. https://doi.org/10. 1002/jmv. 25804

138. Garcia-Villalon D, Gil-Fernandez C (1991) Antiviral activity of sulfated polysaccharides against African swine fever virus. Antiviral Res 15:139-148. https://doi.org/10.1016/0166-3542(91) 90031-1

139. Moakes RJA, Davies SP, Stamataki Z, Grover LM (2021) Formulation of a composite nasal spray enabling enhanced surface coverage and prophylaxis of SARS-COV-2. Adv Mater. https:// doi.org/10.1002/adma.202008304

140. Haldar J, An D, Cienfuegos L, Chen J, Klibanov A (2006) Polymeric coatings that inactivate both influenza virus and pathogenic bacteria. Proc Natl Acad Sci USA 103:17667

141. Liu H, Elkin I, Chen J, KLibanov AM (2015) Why do some immobilized $\mathrm{N}$-alkylated polyethylenimines far surpass others in inactivating influenza viruses? Biomacromol 16:351-356

142. Rana MM (2021) Polymer-based nano-therapies to combat COVID-19 related respiratory injury: progress, prospects, and challenges. J Biomat Sci Polymer Edition. https://doi.org/10. 1080/09205063.2021.1909412

143. Catoira MC, Fusaro L, Di Francesco D, Ramella M, Boccafoshi F (2019) Overview of natural hydrogels for regenerative medicine applications. J Mater Sci Mater Med 30:1-10

144. Matthews et al (2001) US Patents

145. Kandeel M, Ibrahim A, Fayez M, Al-Nazzawi M (2020) From SARS and MERS CoVs to SARS-CoV-2: Moving toward more biased codon usage in viral structural and nonstructural genes 92: 660-666.

146. Clausen TM, Sandoval DR, Spliid CB, Pihl J, Perrett HR, Painter CD, Narayanan A, Majowicz SA, Kwong EM, McVicar RN, Thacker BE, Glass CA, Yang Z, Torres ZL, Golden GJ, Bartels PL, Porell RN, Garretson A, Laubach L, Feldman J, Yin X, Pu Y, Hauser BM, Caradonna TM, Kellman BP, Martino C, Gordts PLSM, Chanda SK, Schmidt AG, Godula K, Leibel SL, Jose J, Corbett KD, Ward AB, Carlin AF, Esko JD (2020) SARS-CoV-2 infection depends on cellular heparan sulfate and ACE2. Cell 183:1043-1057

147. Dey R, Joshi AB, Oliveira F, Pereira L, Guimara es-Costa AB, Serafim TD, Waldione^ de C, Coutinho-Abreu IV, Bhattacharya P, STownsend, Aslan H, Perkins A, Karmakar S, Ismail N, Karetnick M, Meneses C, Duncan R, Nakhasi HL, Valenzuela JG, Kamhaw S (2018) Gut microbes egested during bites of infected sand flies augment severity of leishmaniasis via inflammasomederived IL-1b. Cell Host \& Microbe 23:134-143

148. Orlowski P, Kowalczyk A, Tomaszewska E, Ranoszek-Soliwoda K, Wegrzyn A, Grzesiak J, Celichowski G, Grobelny J, Eriksson K, Krzyzowska M (2018) Antiviral activity of tannic acid modified silver nanoparticles: potential to activate immune response in herpes genitalis. Viruses-Basel 10:524

149. Du T, Liang J, Dong N, Lu J, Fu Y, Fang L, Xiao S, Han H (2018) Glutathione-Capped Ag2S nanoclusters inhibit coronavirus proliferation through blockage of viral RNA synthesis and budding. ACS Appl Mater Interfaces 10:4369

150. Tavakoli A, Hashemzadeh M (2020) Inhibition of herpes simplex virus type 1 by copper oxide nanoparticles. J Virol Methods. 275:113688

151. Hang X, Peng H, Song H, Qi Z, Miao X, Xu W (2015) Antiviral activity of cuprous oxide nanoparticles against hepatitis $\mathrm{C}$ virus in vitro. J Virol Methods 222:150
152. Lévy R, Thanh N, Doty R, Hussain I, Nichols R, Schiffrin D, Brust M, Fernig D (2004) Rational and combinatorial design of peptide capping ligands for gold nanoparticles. J Am Chem Soc 126:10076

153. Li C, Zheng L, Yang X, Wan X, Wu W, Zhen S, Li Y, Luo L, Huang C (2016) DNA-AuNP networks on cell membranes as a protective barrier to inhibit viral attachment, entry and budding. Biomaterials 77:216

154. Bawage S, Tiwari P, Singh A, Dixit S, Pillai S, Dennis V, Singh S (2016) Gold nanorods inhibit respiratory syncytial virus by stimulating the innate immune response. Nanomed-Nanotechnol $12: 2299$

155. Carja G, Grosu E, Petrarean C, Nichita N (2015) Self-assemblies of plasmonic gold/layered double hydroxides with highly efficient antiviral effect against the hepatitis B virus. Nano Res $8: 3512$

156. Zhao Z, Cui H, Song W, Ru X, Zhou W, Yu X, A simple magnetic nanoparticles-based viral RNA extraction method for efficient detection of SARS-CoV-2, (n.d.). https//doi.org/https://doi. org/10.1101/2020.02.22.961268.

157. Zhu X, Wang X, Han L, Chen T, Wang L, Li H, Li S, He L, Fu X, Chen S, Xing M, Chen H, Wang Y, Reverse transcription loopmediated isothermal amplification combined with nanoparticlesbased biosensor for diagnosis of COVID-19, (n.d.). https://doi. org/10.1101/2020.03.17.20037796.

158. Du T, Liang J, Dong N, Liu L, Fang L, Xiao S, Han H (2016) Carbon dots as inhibitors of the virus by activating type I interferon response. Carbon 110:278

159. Ye S, Shao K, Li Z, Guo N, Zuo Y, Li Q, Lu Z, Chen L, He Q, Han $H$ (2015) Antiviral activity of graphene oxide: how sharp edged structure and charge matter. ACS Appl Mater Interfaces 7:21571

160. Nikazar VS, Sivasankarapillai A, Rahdar S, Gasmi PS, Anumol MS (2020) Shanavas, revisiting the cytotoxicity of quantum dots: an in-depth overview. Biophys Rev. https://doi.org/10.1007/ s12551-020-00653-0

161. Carter DC, Wright B, Jerome WG, Rose JP, Wilson E (2020) A unique protein self-assembling nanoparticle with significant advantages in vaccine development and production. J Nanomater. https://doi.org/10.1155/2020/4297937

162. Pillai AM, Sivasankarapillai VS, Rahdar A, Joseph J, Sadeghfar F, Anuf R, Rajesh AK, Kyzas GZ (2020) Green synthesis and characterization of zinc oxide nanoparticles with antibacterial and antifungal activity. J Mol Struct. 1211:128107. https://doi. org/10.1016/j.molstruc.2020.128107

163. Han Y, Král P (2020) Computational design of ACE2-based peptide inhibitors of SARS-CoV-2. ACS Nano. https://doi.org/10. 1021/acsnano.0c02857

164. Mansoor F, Earley B, Cassidy JP, Markey B, Doherty S, Welsh MD (2015) Comparing the immune response to a novel intranasal nanoparticle PLGA vaccine and a commercial BPI3V vaccine in dairy calves. BMC Vet Res. https://doi.org/10.1186/ s12917-015-0481-y

Publisher's Note Springer Nature remains neutral with regard to jurisdictional claims in published maps and institutional affiliations. 